\title{
A comparative study of wood sawdust and plastic smoke particulate matter with a focus on spectroscopic, fluorescent, oxidative, and neuroactive properties
}

\author{
Alla Tarasenko ${ }^{1} \cdot$ Natalia Pozdnyakova $^{1} \cdot$ Konstantin Paliienko $^{1} \cdot$ Arsenii Borysov $^{1} \cdot$ Natalia Krisanova $^{1}$. \\ Artem Pastukhov ${ }^{1}$. Olexander Stanovyi ${ }^{2}$. Olena Gnatyuk ${ }^{2}$. Galina Dovbeshko ${ }^{2} \cdot$ Tatiana Borisova $^{1}$
}

Received: 16 August 2021 / Accepted: 14 January 2022 / Published online: 25 January 2022

(c) The Author(s), under exclusive licence to Springer-Verlag GmbH Germany, part of Springer Nature 2022

\begin{abstract}
Here, water-suspended smoke aerosol preparation was synthesized from biomass-based fuel, i.e., a widespread product for residential heating, wood sawdust (WP) (pine, poplar, and birch mixture), and its properties were compared in parallel experiments with the smoke preparation from plastics (PP). Molecular groups in the PM preparations were analyzed using Raman and Fourier-transform infrared spectroscopy. WP was assessed in neurotoxicity studies using rat cortex nerve terminals (synaptosomes). Generation of spontaneous and $\mathrm{H}_{2} \mathrm{O}_{2}$-evoked reactive oxygen species (ROS) detected using fluorescent dye $2^{\prime}, 7^{\prime}$-dichlorofluorescein in nerve terminals was decreased by WP. In comparison with PP, WP demonstrated more pronounced reduction of spontaneous and $\mathrm{H}_{2} \mathrm{O}_{2}$-evoked ROS production. WP completely inhibited glutamate receptor agonist kainate-induced ROS production, thereby affecting the glutamate receptor-mediated signaling pathways. WP decreased the synaptosomal membrane potential in fluorimetric experiments and the synaptosomal transporter-mediated uptake of excitatory and inhibitory neurotransmitters, L- $\left[{ }^{14} \mathrm{C}\right]$ glutamate and $\left[{ }^{3} \mathrm{H}\right] \gamma$-aminobutyric acid (GABA), respectively. PP decreased the ambient synaptosomal level of $\left[{ }^{3} \mathrm{H}\right] \mathrm{GABA}$, whereas it did not change that of $\mathrm{L}-\left[{ }^{14} \mathrm{C}\right]$ glutamate. Principal difference between WP and PP was found in their ability to influence the ambient synaptosomal level of $\left[{ }^{3} \mathrm{H}\right] \mathrm{GABA}$ (an increase and decrease, respectively), thereby showing riskiness in mitigation of synaptic inhibition by PP and triggering development of neuropathology.
\end{abstract}

Keywords Air pollution particulate matter $\cdot$ Wood sawdust $\cdot$ Plastics $\cdot$ Oxidative potential $\cdot$ Neurotoxicity $\cdot$ Environmentally derived health threats

\begin{tabular}{|c|c|}
\hline \multicolumn{2}{|c|}{ Abbreviations } \\
\hline PM & Particulate matter \\
\hline WP & $\begin{array}{l}\text { Water-suspended wood sawdust smoke aerosol } \\
\text { preparations }\end{array}$ \\
\hline PP & $\begin{array}{l}\text { Water-suspended plastic smoke aerosol } \\
\text { preparations }\end{array}$ \\
\hline GABA & $\gamma$-Aminobutryic acid \\
\hline EDTA & Ethylenediaminetetraacetic acid \\
\hline
\end{tabular}

Responsible Editor: Lotfi Aleya.

Tatiana Borisova

1 Department of Neurochemistry, Palladin Institute of Biochemistry, National Academy of Sciences of Ukraine, 9 Leontovicha str, Kiev 01054, Ukraine

2 Department of Physics of Biological Systems, Institute of Physics, National Academy of Sciences of Ukraine, 46 Nauky Ave, Kiev 03680, Ukraine

\author{
HEPES 4-(2-Hydroxyethyl)-1-piperazineethanesulfonic \\ acid \\ ROS Reactive oxygen species \\ DCF 2',7'-Dichlorofluorescein \\ UV-Vis Ultraviolet-visible
}

\section{Introduction}

Neurological disorders are the 3rd reason of disability and premature death in the European Union, and this burden is expected to be increased (Deuschl et al. 2020; Karthika et al. 2021) and significantly aggravated by COVID pandemic because of "long COVID" neurological complications (Jarrahi et al. 2020; The Lancet Neurology 2021). Etiology of neurological disorders still remains unclear, and their stable expansion is linked to air pollution with $\mathrm{PM}_{2.5}$ (particulate matter, size of which is less than 
$2.5 \mu \mathrm{m})$, which disperses globally, traveling across state boundaries, oceans, and continents (Jiang et al. 2015; Zhang et al. 2017), targeting nervous system, and triggering development of neurological disorders and complications, e.g., lowered cognitive function, autism, neurodegenerative disease, dementia, and stroke (Landrigan et al. 2018). A possibility of interaction of SARS-CoV-2 with air pollution PM serving as a potential carrier for transmission of SARS-CoV-2 immobilized at their surface to the nervous system, and neurological symptom enhancer is also not excluded (Borisova and Komisarenko 2020; Rahman et al., 2020).

One of the main sources of carbon-containing PM emissions is biomass burning aerosol that mainly includes fires of forests, agricultural waste, and wood combustion for residential heating spread in developed countries (Fuzzi et al. 2015). Wood combustion and biomass burning contribution to organic carbon at European sites is between 30 and 75\% (Gilardoni et al. 2016), and water-suspended carbon of air pollution can also pollute water recourses worldwide. Chemical and physical features of wood burning particles vary in dependence on the combustion conditions and biomass types. Wood is utilized for fuel as conventional wood (woodchips) and wood pellets made from compacted sawdust (Saosee et al. 2020). Wood pellets are gaining attractiveness as a biomass-based fuel for heat and electricity production (Thraen et al. 2017; Sun and Niquidet 2017) and the wood pellet demand has enlarged resulting in its increased production (Jonsson and Rinaldi 2017). Global production of wood pellets increased considerably by $14 \%$ per year since 2011 (Thraen et al. 2017) and was estimated as 52.7 million tonnes in 2018 ("World Pellet Map - European Pellet Council," 2021).

A large part of "synthetic" precursors of carbon-containing PM is plastics that is still utilized being subjected to open-fire combustion. Very recently, we synthesized in the laboratory conditions water-suspended smoke samples from plastic, which were appropriate for biological experiments and contained major nano-sized ( $30 \mathrm{~nm}$ ) PM fraction. The smoke samples from plastic revealed oxidative activity in brain nerve terminals and decreased the membrane potential and synaptic vesicle acidification and functioning of excitatory/inhibitory neurotransmitter transporters, thereby provoking presynaptic malfunctioning and triggering neurological consequences (Borysov et al. 2020). Glutamate and $\gamma$-aminobutyric acid (GABA) are the crucial neurotransmitters for excitatory and inhibitory signal transduction in the central nervous system. Impairments of their transport parameters are involved in pathogenesis of main neurological complications and disorders. Engineered carbon-containing nanoparticles synthesized by combustion of organics also significantly dysregulated the abovementioned presynaptic processes (Borisova et al. 2015, 2017; Borisova 2019).
The aims of this study were as follows: (1) to collect in the laboratory conditions water-suspended smoke aerosol preparations from wood sawdust (pine, poplar, and birch mixture) (WP) using recently developed method (Borysov et al. 2020) for water-suspended plastic smoke PM preparations (PP); (2) to define the average size of PM in WP using dynamic light scattering; (3) to analyze optical and fluorescence properties, and Raman and Fourier-transform infrared (FTIR) spectra of WP, (4) to assess neurotoxic properties studying its activity in isolated rat cortex nerve terminals (synaptosomes), in particular, to analyze oxidative properties and key characteristics that determine synaptic neurotransmission, namely, $\mathrm{Na}^{+}$-dependent transporter-mediated uptake and the ambient levels of glutamate and GABA; and (4) to compare above WP characteristics with PP ones in parallel experiments.

\section{Methods and materials}

\section{Laboratory synthesis and collection of wood sawdust smoke aerosol}

Smoke of wood sawdust (pine, poplar, and birch mixture) was collected in the laboratory conditions during the entire flaming, mixed combustion phase (when the flaming and smoldering phases are present at the same time), and smoldering phase. Smoke emissions were monitored using Air Quality Monitor/Mini Laser $\mathrm{PM}_{2.5}$ Monitor/SDL607. Wood (10 g) was combusted, smoke emissions were collected, and $4000 \mathrm{ml}$ of smoke aerosol was sampled and bubbled through $5 \mathrm{ml}$ of water. WP enriched with nano-sized PM were obtained by filtration through Millipore filters $(0.45 \mu \mathrm{m})$ (Borysov et al. 2020), because the most harmful to human health is the nano-sized PM (Borisova 2018). The obtained WP was dried to measure the concentration of particulate smoke components.

\section{Dynamic light scattering}

Particle size in WP was examined using dynamic light scattering with a laser correlation spectrometer Zetasizer-3, Malvern Instruments (UK) equipped with He-Ne laser LGN-111 ( $p=25 \mathrm{~mW}, k=633 \mathrm{~nm}$ ) according to (Borysov et al. 2020).

\section{Optical and fluorescent properties}

The optical properties of WP and PP were obtained with ultraviolet-visible absorption and photoluminescence spectroscopy using a Lambda Bio (PerkinElmer) spectrophotometer and QuantaMaster (PTI) spectrofluorimeter. 


\section{Raman and FTIR spectroscopy}

The Raman spectra of WP were recorded using a custommade Raman instrument pre-verified and equipped with a $40 \times$ objective microscope. A Verdi G laser, Coherent Inc. with a wavelength of $532 \mathrm{~nm}$ was used to excite the WP; the laser power on the sample was $30 \mathrm{~mW}$. The scattered light from the sample was collected by the lens and filtered using two filters (RazorEdge $0^{\circ}$ Longpass filter, Semrock). Raman scattered light was focused on a monochromator

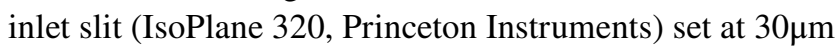
to deflect unfocused light and have a high spectral resolution. The monochromator was equipped with a diffraction grating of 600 lines $/ \mathrm{mm}$, and the calculated spectral resolution was approximately $2 \mathrm{~cm}^{-1}$. A CCD (PyLoN: 400BReXcelon CCD, Princeton Instruments), cryogenically cooled at $-120{ }^{\circ} \mathrm{C}$, was applied as detector.

WP was analyzed using FTIR spectrometer INVENIO-R (Bruker, Germany). Samples for the Raman scattering spectra and infrared absorption were prepared by applying a drop

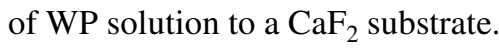

\section{Ethical statement in animal experiments}

Males, Wistar rats, with body weight of $100-120 \mathrm{~g}$, were kept in a temperature-controlled room at $22-23{ }^{\circ} \mathrm{C}$ using the institutional facilities, and they were provided ad libitum with water and dry food. All experiments with animals were carried out according to the ARRIVE guidelines (McGrath et al. 2010). The protocol was approved by the Animal Care and Use Committee of the Institute, the Protocol \#5 from $01 / 09 / 2020$. Total number of rats used in this study was 30 . To save animals, synaptosomal preparations were shared between radiolabeled and fluorescence experiments. As a result, 9 separate rats were used for analysis of the L- $\left[{ }^{14} \mathrm{C}\right]$ glutamate uptake; 3 separate rats and 6 shared rats $-\left[{ }^{3} \mathrm{H}\right]$ GABA uptake; 12 separate rats - the ambient levels of L- $\left[{ }^{14} \mathrm{C}\right]$ glutamate and $\left[{ }^{3} \mathrm{H}\right] \mathrm{GABA} ; 6$ separate rats and 3 shared rats - fluorescence measurements.

\section{Inclusion and exclusion criteria}

There were no exclusions in each experimental group of animals. The exact value of $n$ in each experimental group was indicated in the figures and tables. The quality of synaptosomal isolation procedure from rat brain and synaptosome viability was controlled in each experiment by specific criteria, i.e., the value of the ambient level of $\mathrm{L}-\left[{ }^{14} \mathrm{C}\right]$ glutamate in the control nerve terminal preparations that characterized active dynamic glutamate turnover across the plasma membrane of nerve terminals (Borisova and Borysov 2016; Borisova 2016). There were no data points excluded from analyses because of their biologically implausible values.

\section{The rat cortex nerve terminals (synaptosomes)}

The synaptosomal preparations were obtained by differential and Ficoll-400 density gradient centrifugation of homogenates according to the method described by Cotman (Cotman 1974) with slight modifications (Borisova and Himmelreich 2005; Borisova 2014; Tarasenko et al. 2010). The protein concentrations were monitored according to Larson (Larson et al. 1986). WP aliquots were added to the synaptosomal suspensions and incubated for $10 \mathrm{~min}$.

\section{The synaptosomal membrane potential $\left(E_{m}\right)$}

The membrane potential of synaptosomes was measured using the potentiometric fluorescent dye rhodamine $6 \mathrm{G}$ $(0.5 \mu \mathrm{M})$ based on its potential-dependent binding to the membranes (Borysov et al. 2014, 2018; Pozdnyakova et al. 2016). Fluorescence measurements of rhodamine $6 \mathrm{G}$ were carried out using a fluorescence spectrofluorometer QuantaMaste $^{\mathrm{TM}} 40$ (PTI, Inc., Canada) at $528 \mathrm{~nm}$ (excitation) and $551 \mathrm{~nm}$ (emission) wavelengths.

\section{Reactive oxygen species (ROS) in nerve terminals}

A cell-permeable non-fluorescent probe, $2^{\prime}, 7^{\prime}$-dichlorodihydro-fluoresceindiacetate (H2-DCFDA), was applied to measure ROS generation in synaptosomes according to (Borysov et al. 2020). 2',7'-dichlorofluorescein (DCF) fluorescence alterations were recorded at excitation and emission wavelengths of 502 and $525 \mathrm{~nm}$, respectively (slit bands were $2 \mathrm{~nm}$ each) using a fluorescence spectrofluorometer QuantaMaster ${ }^{\mathrm{TM}} 40$ (PTI, Inc., Canada).

\section{The transporter-mediated $\mathrm{L}-\left[{ }^{14} \mathrm{C}\right]$ glutamate uptake by nerve terminals}

The uptake was initiated by the addition of $10 \mu \mathrm{M}$ glutamate supplemented with L- $\left[{ }^{14} \mathrm{C}\right]$ glutamate $(420 \mathrm{nM}, 0.1 \mu \mathrm{Ci} / \mathrm{ml})$. The synaptosomal transporter-mediated $\mathrm{L}-\left[{ }^{14} \mathrm{C}\right]$ glutamate uptake was measured using liquid scintillation counting with Sigma-Fluor ${ }^{\circledR}$ High Performance LSC Cocktail (Soldatkin et al. 2015).

\section{The ambient level of L- $\left[{ }^{14} \mathrm{C}\right]$ glutamate in nerve terminal preparations}

The synaptosomes were loaded with L- $\left[{ }^{14} \mathrm{C}\right]$ glutamate $(1 \mathrm{nmol} / \mathrm{mg}$ of protein, $238 \mathrm{mCi} / \mathrm{mmol})$ in the standard saline solution at $37^{\circ} \mathrm{C}$ for $10 \mathrm{~min}$. The ambient levels of $\mathrm{L}-\left[{ }^{14} \mathrm{C}\right]$ glutamate in the synaptosomal preparations were measured according to (Borisova et al. 2016; Borisova 2018) using liquid scintillation counting with Sigma-Fluor® High Performance LSC Cocktail. 


\section{The transporter-mediated $\left[{ }^{3} \mathrm{H}\right] \mathrm{GABA}$ uptake by nerve terminals}

The uptake was initiated by the addition of GABA and $\left[{ }^{3} \mathrm{H}\right]$ GABA $(1 \mu \mathrm{M}$ or $50 \mathrm{nM}$ and $4.7 \mu \mathrm{Ci} / \mathrm{ml}$, respectively) and terminated by filtering aliquots through Whatman GF/C filters as described in (Pozdnyakova 2017).

\section{The ambient level of $\left[{ }^{3} \mathrm{H}\right] \mathrm{GABA}$ in nerve terminal preparations}

The synaptosomes were loaded with $\left[{ }^{3} \mathrm{H}\right] \mathrm{GABA}(50 \mathrm{nM}$, $4.7 \mu \mathrm{Ci} / \mathrm{ml}$ ) in the standard saline solution for $10 \mathrm{~min} .\left[{ }^{3} \mathrm{H}\right]$ GABA radioactivity was measured in aliquots of supernatants by liquid scintillation counting with Sigma-Fluor ${ }^{\circledR}$ High Performance LSC Cocktail according to (Pozdnyakova et al. 2015).

\section{Statistical analysis}

The results are expressed as the mean \pm S.E.M. of $n$ independent experiments. Experimental data on the effects of control vs WP or PP were analyzed using one-way ANOVA. The accepted level of significance was set at $p<0.05$.

\section{Materials}

EGTA, EDTA, HEPES, Ficoll 400, aminooxiacetic acid, D-glucose, sucrose, Whatman GF/C filters, the fluorescent dye 2',7'-dichlorofluorescein, Sigma-Fluor ${ }^{\circledR}$ High Performance LSC Cocktail, organic counting scintillant (OCS) and the analytical grade salts were purchased from Sigma (St. Louis, MO, USA); L- $\left[{ }^{14} \mathrm{C}(\mathrm{U})\right]$ glutamate, $\left[{ }^{3} \mathrm{H}\right] \mathrm{GABA}$ $\left(\boldsymbol{\gamma}-\left[2,3-{ }^{3} \mathrm{H}(\mathrm{N})\right]\right.$-aminobutyric acid) were from PerkinElmer (Waltham, MA, USA). Rhodamine 6G were obtained from Molecular Probes (USA).

\section{Results}

\section{Size of particles in WP}

Analysis of the average size of particles in WP was performed by dynamic light scattering. Distribution of particles' population by number (Fig. 1) was assessed and peak analysis demonstrated that the major number of particles in WP was $29.7 \mathrm{~nm}$ in diameter. Studying PP, the similar distribution of particles' population by number was revealed, where the major number of particles was $34 \mathrm{~nm}$ in diameter (Borysov et al. 2020).

\section{Optical and fluorescent properties of WP and PP}

The optical properties of WP were characterized using ultraviolet-visible (UV-Vis) absorption and photoluminescence spectroscopy. Figure 2a represents UV-Vis absorption spectrum of WP (versus PP) recorded with a Lambda Bio (Perkin Elmer) spectrophotometer. Similarly to PP, the absorbance of WP was mainly registered in the UV region (generally within the range of 200-350 nm), but in contrast to PP, it had a pronounced peak at around of $275 \mathrm{~nm}$. Photoluminescence experiments carried out using QuantaMaster (PTI) spectrofluorimeter have demonstrated that
Fig. 1 Dynamic light scattering histograms of WP: distribution of particle populations by number. Five measurements each during $1 \mathrm{~min}$, sequentially 1 , red; 2 , blue; 3 , green; 4 , grey; 5 , purple; are present in each histogram. The measurements were performed with a Zetasizer Nanosystem (Malvern Instruments) equipped with a heliumneon laser

\section{Size distribution (s)}

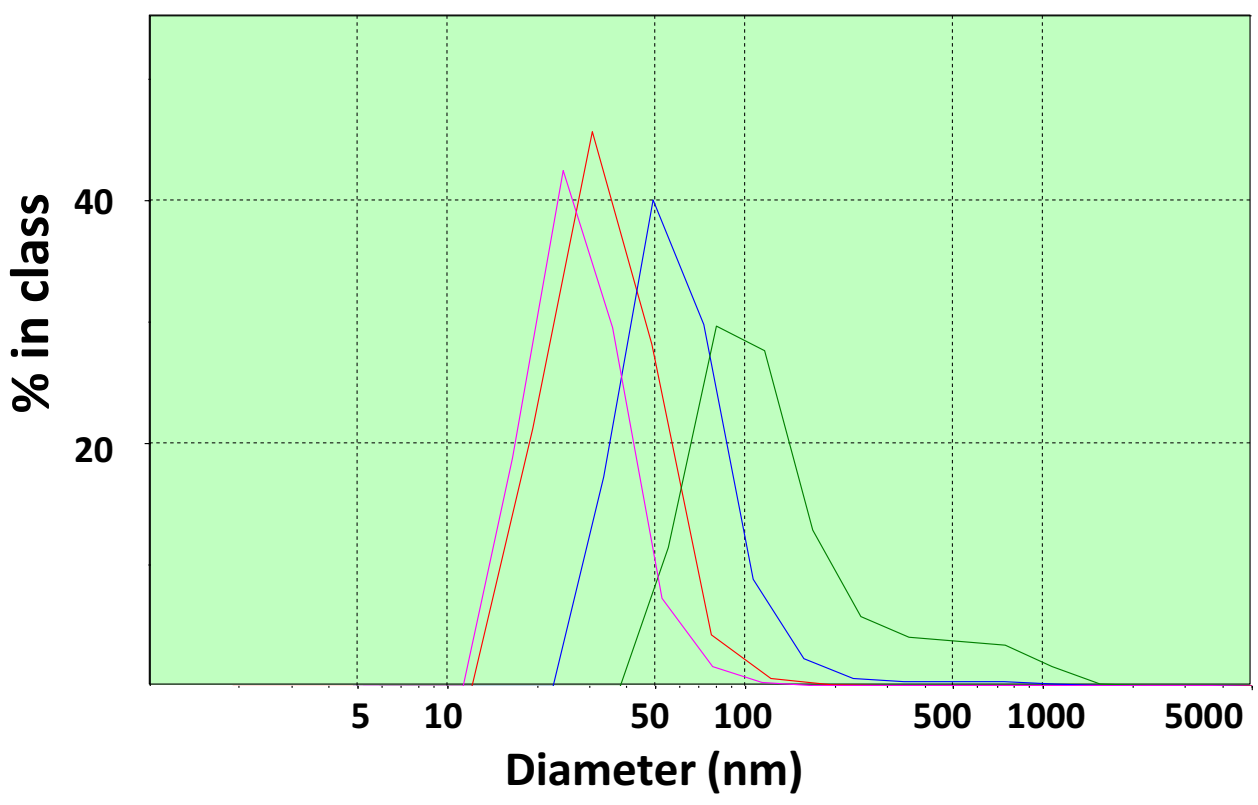




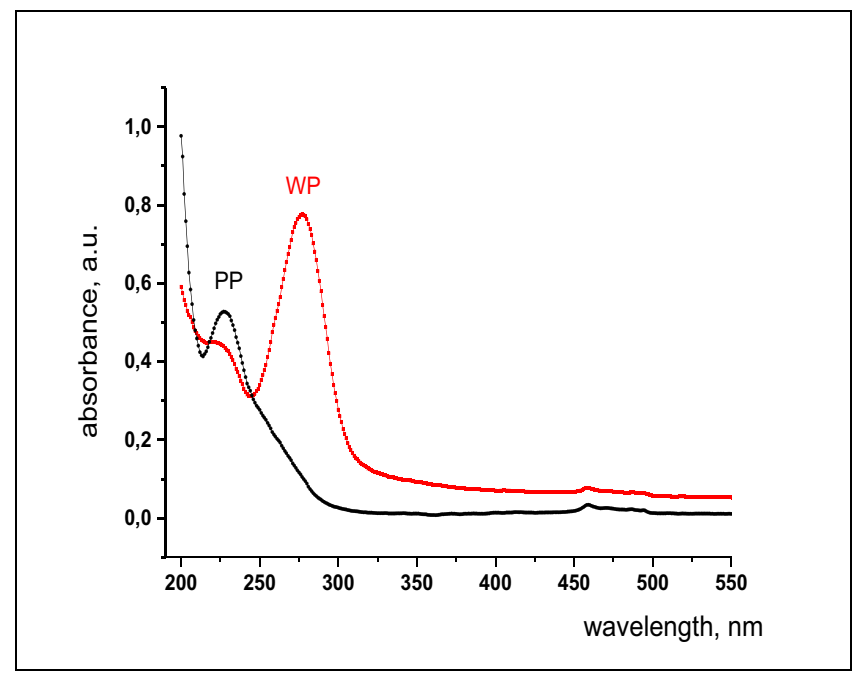

c

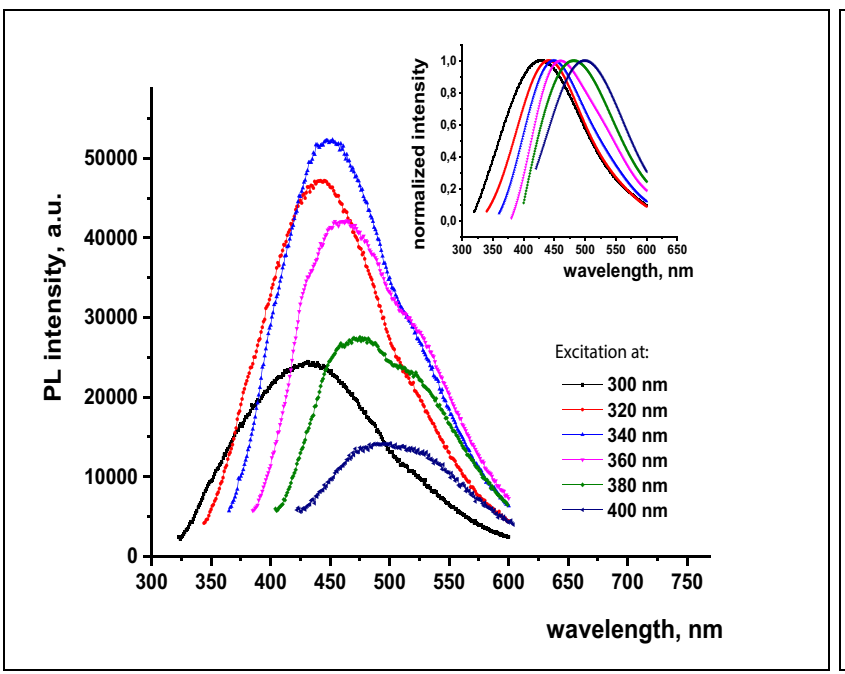

Fig. 2 a UV-Vis absorption spectra of WP and PP; b Photoluminescence (PL) emission spectrum of WP (pine wood) at excitation of $275 \mathrm{~nm}$. c PL emission spectra of WP and $\mathbf{d} \beta$-alanine carbon dots. Insets show emission spectra normalized to their maximum value (a

the excitation of WP at $275 \mathrm{~nm}$ led to fluorescence emission with a maximum wavelength at about $340 \mathrm{~nm}$ that is typical for phenolic derivatives (Fig. 2b). The strong absorbance in the UV region $200-400 \mathrm{~nm}$, followed by a tail extended to the visible region, is known to be a typical feature of carbon dots (Liu et al. 2020), which may be produced during the thermal decomposition of wood. Indeed, the production of several types of carbogenic materials including carbon dots, as a result of hydrothermal carbonization of cellulose, was earlier reported (Woo et al. 2020). Given that one of the unique properties of carbon dots are the dependence of the photoluminescence emission maximum on the excitation wavelength ( $\lambda$ exc), we next b

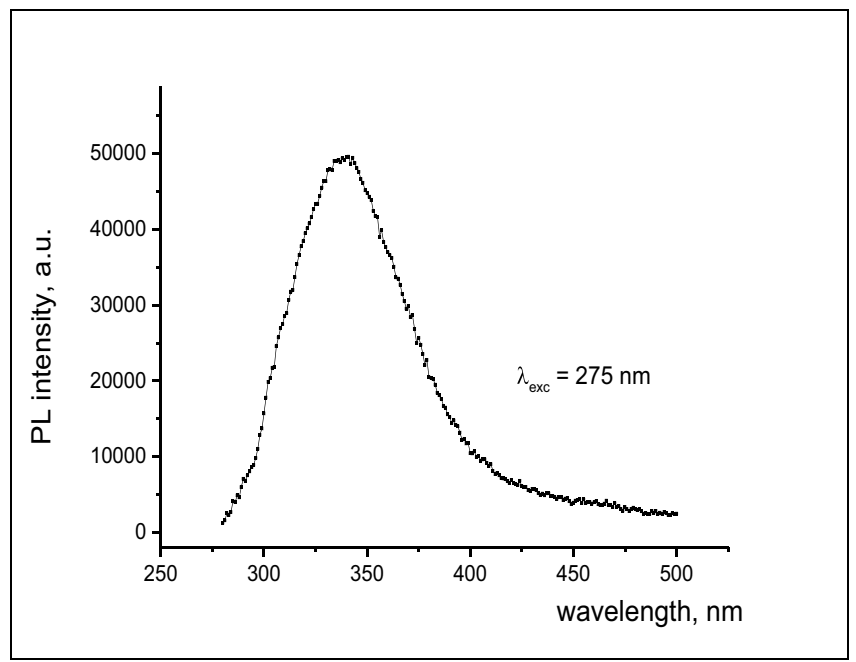

d

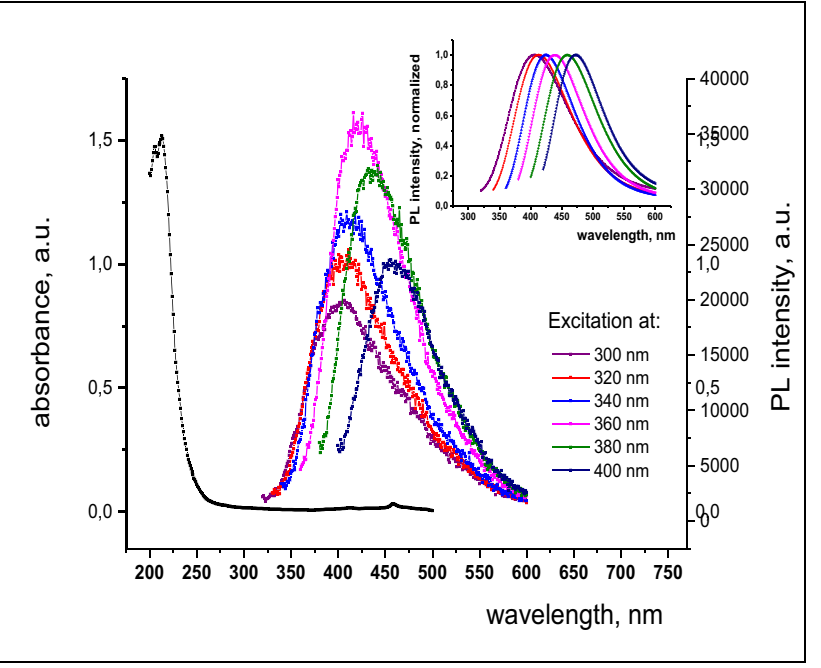

curve fitting was done using 'GCAS' function, OriginPro.9.0), and d also demonstrates the absorption spectrum of $\beta$-alanine carbon dots (black curve)

recorded emission spectra of WP at $\lambda$ exc progressively increased from 300 to $400 \mathrm{~nm}$. Figure $2 \mathrm{c}$ clearly shows that an increase in $\lambda$ exc led to a red-shift of the photoluminescence emission maximum from approximately 430 to $500 \mathrm{~nm}$, thereby demonstrating the excitation-wavelengthdependent photoluminescence behavior typical for carbon dots. These data were similar to those we reported earlier for PP (Borysov et al. 2020), as well as to data obtained for carbon nanoparticles derived from thermal decomposition of $\beta$-alanine (Fig. 2d). As Fig. $2 d$ depicts, $\beta$-alanine carbon nanoparticles absorbed light in a narrow UV-region and similarly with WP, it showed the strong excitation wavelength dependent emission properties. 


\section{Raman and FTIR spectroscopy of WP and PP}

\section{WP experiments}

Using Raman spectroscopy, bands of $1353 \mathrm{~cm}^{-1}$ (D-band) and $1597 \mathrm{~cm}^{-1}$ (G-band) were registered during analysis of separate components of WP (Fig. 3a). These bands were a characteristic for carbon nanodots formed during combustion and however depended on the degree of wood burning, and also, other products of oxidation and uncompleted combustion appeared in the spectra on the background of luminescence (Fig. 3b, c).

FTIR spectra were corrected for baseline and normalized to the $\mathrm{C}=\mathrm{O}$ band in the region of $1715 \mathrm{~cm}^{-1}$ (Fig. 4). In general, Raman and FTIR spectra revealed similar chemical groups in WP (Figs. 3 and 4, Tables 1 and 2).

\section{PP experiments}

Table 2 demonstrates frequencies of PP. Raman and FTIR spectra of PP were presented in our previous study in the Supplementary Materials (Borysov et al. 2020).

The bands seen in the smoke suspension spectra were mainly related to lignin and its pyrolysis products. Analysis of the FTIR absorption spectra of separate components of WP was performed in two areas $3800-2400 \mathrm{~cm}^{-1}$ and $1850-950 \mathrm{~cm}^{-1}$. The absorption region with a maximum in the range of $3406-3383 \mathrm{~cm}^{-1}$ belonged to the molecular $\boldsymbol{a}$

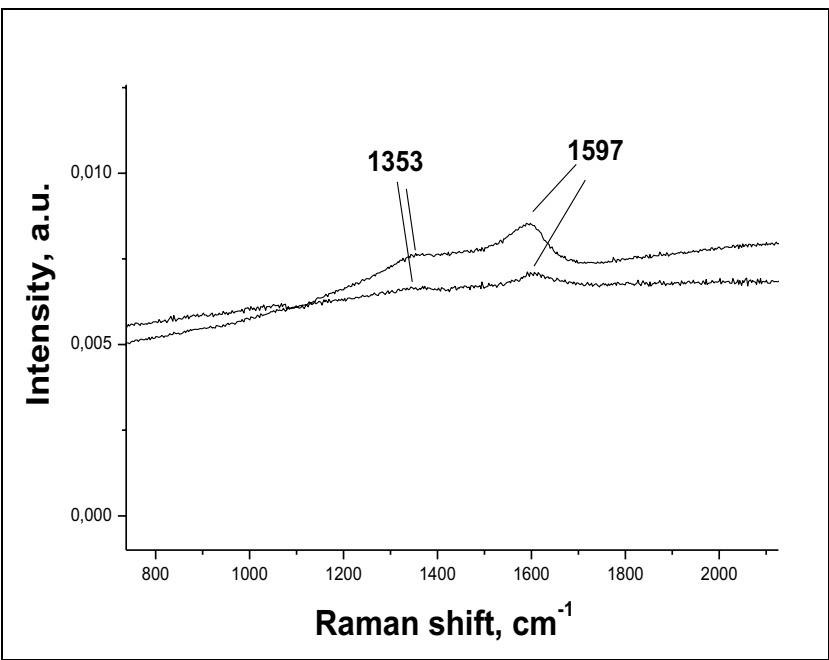

C

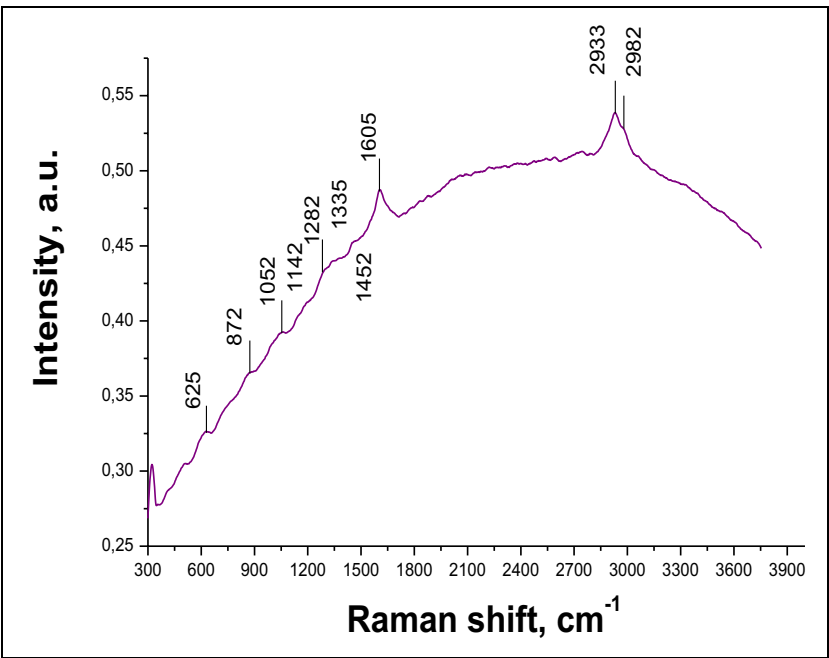

b

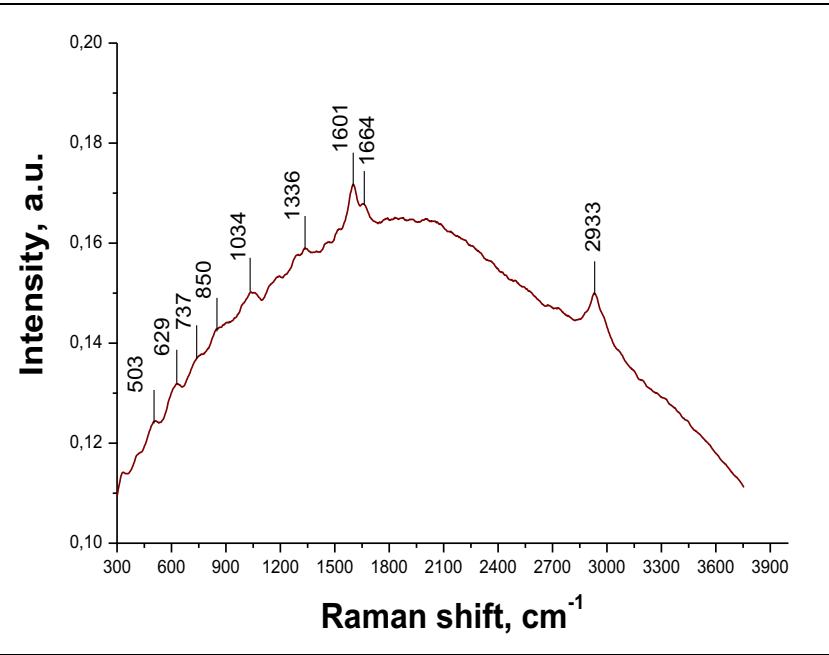

Fig. 3 Raman spectra of separate WP components, i.e., birch (a), poplar (b) and pine (c) wood 
Fig. 4 FTIR spectra of separate WP components, i.e., birch (green line), poplar (blue line), and pine (red line) wood, obtained in the range of $3800-2300 \mathrm{~cm}^{-1}$ (a) and $1850-950 \mathrm{~cm}^{-1}$ (b) a

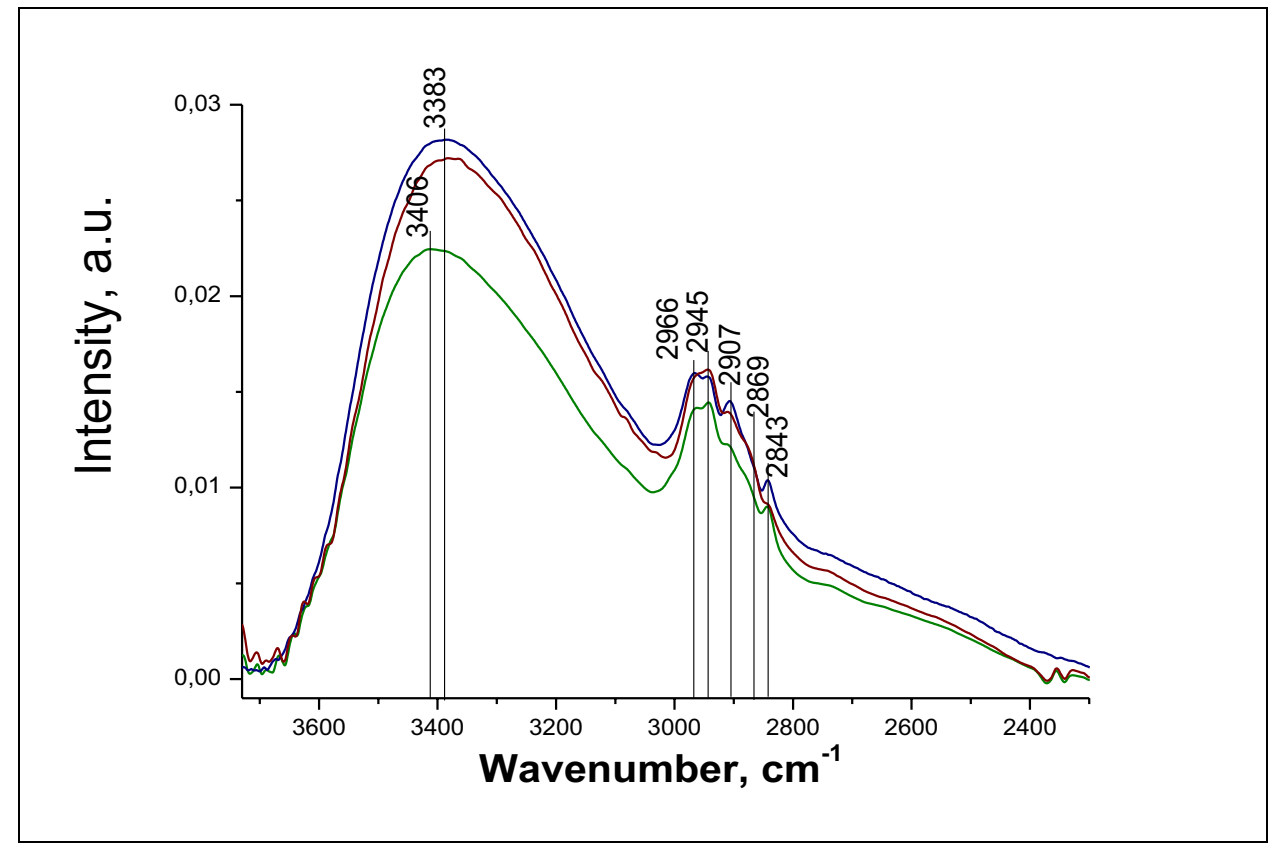

b

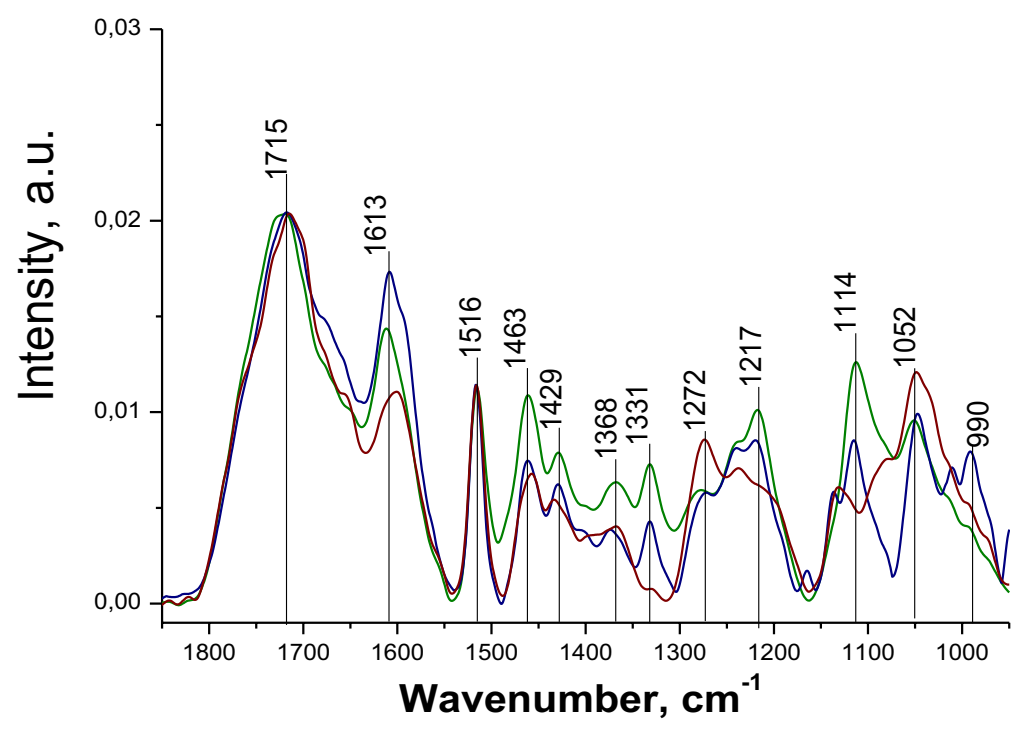

groups of $\mathrm{OH}$, which is part of the phenolic, hydroxyl, and carboxyl groups (Zhong and Jang 2014; Fan et al. 2016). In addition, bands of stretching vibrations of aliphatic $\mathrm{CH}_{2}$ (2907 and $2843 \mathrm{~cm}^{-1}$ ) and $\mathrm{CH}_{3}$ (2966, 2945, and $2880 \mathrm{~cm}^{-1}$ ) molecular groups have been registered in this region. In particular, the band $2869 \mathrm{~cm}^{-1}$ can be attributed to the methoxy group $\left(\mathrm{O}-\mathrm{CH}_{3}\right)$ of lignin (Dias Júnior et al. 2019). The contribution of $\mathrm{CH}_{2}$ groups of poplar wood was slightly greater than that of birch and pine woods. The band in the region $1715-1717 \mathrm{~cm}^{-1}$ referred to the valence vibrations of the molecular group $\mathrm{C}=\mathrm{O}$, which was a part of the carboxyl groups $(\mathrm{HO}-\mathrm{C}=\mathrm{O})$ and carbonyl groups $(\mathrm{H}-\mathrm{C}=\mathrm{O}$ ) of aldehydes and ketones (Zhong and Jang 2014; Fan et al. 2016). In untreated wood, this band made a much smaller contribution and was in the higher frequency position (1720-1725 $\mathrm{cm}^{-1}$ ) and referred to unbound (unconjugated) $\mathrm{C}=\mathrm{O}$. After the pyrolysis process, there was an increase in the contribution of $\mathrm{C}=\mathrm{O}$ and its low-frequency 
Table 1 Frequencies of separate WP components

\begin{tabular}{|c|c|c|c|}
\hline Birch & Poplar & Pine & Frequencies \\
\hline \multirow[t]{2}{*}{3406} & & & str $\mathrm{OH}$ \\
\hline & 3383 & 3380 & str $\mathrm{OH}$ \\
\hline 2962 & 2966 & 2965 & str $\mathrm{CH}_{3}$ \\
\hline 2942 & 2945 & 2944 & str $\mathrm{CH}_{3}$ \\
\hline 2912 & 2907 & 2911 & str $\mathrm{CH}_{2}$ \\
\hline 2880 & 2880 & 2883 & str $\mathrm{CH}_{3}$ \\
\hline 2869 & 2869 & 2869 & str $\mathrm{O}-\mathrm{CH}_{3}$ lignin \\
\hline 2843 & 2843 & 2843 & str $\mathrm{CH}_{2}$ \\
\hline 1728 & & & str $\mathrm{C}=\mathrm{O}$ carboxyl \\
\hline \multirow[t]{2}{*}{1715} & 1717 & 1715 & str $\mathrm{C}=\mathrm{O}$ carboxyl \\
\hline & & 1702 & str $\mathrm{C}=\mathrm{O}$ ketonic and/or aldehydic \\
\hline 1682 & 1678 & 1682 & $\operatorname{str} \mathrm{C}=\mathrm{O}$ \\
\hline 1551 & 1658 & 1652 & $\operatorname{str} \mathrm{C}=\mathrm{O}, \mathrm{C}=\mathrm{C}$ ketones, lignin \\
\hline \multirow[t]{2}{*}{1613} & 1608 & 1613 & $\operatorname{str} \mathrm{C}=\mathrm{C}$ \\
\hline & 1593 & 1600 & $\operatorname{str} \mathrm{C}=\mathrm{C}$ \\
\hline 1516 & 1516 & 1516 & str $\mathrm{C}=\mathrm{C}$ lignin \\
\hline 1463 & 1460 & 1455 & asym def $\mathrm{CH}_{3}$ in lignin \\
\hline 1429 & 1429 & 1433 & def $\mathrm{CH}$ in lignin and cadbohydrates, def $\mathrm{CH}_{2}$ \\
\hline 1368 & 1372 & 1363 & def $\mathrm{CH}$ in cellulose and hemicellulose, cadbohydrates, \\
\hline 1331 & 1331 & 1331 & $\mathrm{C}-\mathrm{O}$ \\
\hline \multirow[t]{2}{*}{1277} & 1273 & 1274 & $\mathrm{C}-\mathrm{O}$ \\
\hline & 1240 & 1238 & $\mathrm{C}-\mathrm{O}$ lignin \\
\hline \multirow[t]{3}{*}{1217} & 1220 & 1212 & Str $\mathrm{C}-\mathrm{O}-\mathrm{C}$ syringyl ring \\
\hline & 1165 & & $\mathrm{C}-\mathrm{O}-\mathrm{C}$ cellulose and hemicellulose \\
\hline & 1136 & 1135 & $\mathrm{C}-\mathrm{O}-\mathrm{C}$ lignin \\
\hline \multirow[t]{2}{*}{1114} & 1115 & & Aromatic skeletal and str $\mathrm{C}-\mathrm{O}$ lignin and polysaccharides \\
\hline & & 1081 & $\mathrm{C}-\mathrm{O}$ \\
\hline 1052 & 1052 & 1049 & C-O cellulose and hemicellulose, polysaccharides \\
\hline \multicolumn{4}{|l|}{997} \\
\hline 933 & & & \\
\hline
\end{tabular}

shift, which was associated with the degradation of lateral lignin ligaments (Kubovský et al. 2020). The bands in the region of $1680-1650 \mathrm{~cm}^{-1}$ and the intense band in the region of $1613 \mathrm{~cm}^{-1}$ indicated the presence of unsaturated bonds in aromatic rings, including lignin and polysaccharide degradation products. At increased temperature, this 1613 band was mainly unchanged (Dias Júnior et al. 2019). The band in the region of $1500 \mathrm{~cm}^{-1}$ referred to the aromatic $\mathrm{C}=\mathrm{C}$ valence vibrations of benzene rings of lignin that in the process of pyrolysis shifted to a higher frequency region (in this study, the band of $1516 \mathrm{~cm}^{-1}$ ). This band was also associated with the syringyl nucleus of lignin, which was a characteristic of harder woods. Bands in the area of $1516 \mathrm{~cm}^{-1}$ and $1114 \mathrm{~cm}^{-1}$ (C-O lignin) were considered markers of the presence in the atmosphere of smoke from the combustion of biomass, in particular wood (Fan et al. 2016). The region $1463-1368 \mathrm{~cm}^{-1}$ can be attributed to the deformation oscillations of different groups of $\mathrm{CH}$. In particular, the band in the region 1463-1455 referred to the deformation of aromatic $\mathrm{CH}$ and asymmetric lignin $\mathrm{CH}_{3}$ groups. The band in the region $1429-1433 \mathrm{~cm}^{-1}$ can be attributed to deformation of $\mathrm{CH}_{2}$ groups in cellulose and deformation of $\mathrm{CH}$ groups in lignin and carbohydrates. The band in the region $1372-1363 \mathrm{~cm}^{-1}$ was also a deformation $\mathrm{CH}$ groups in carbohydrates, in cellulose and hemicellulose (Timar et al. 2016); $1331 \mathrm{~cm}^{-1} \mathrm{C}-\mathrm{O}$ valence vibrations in the syringyl parts of lignin; $1240-1238 \mathrm{~cm}^{-1} \mathrm{C}-\mathrm{O}$ valence vibrations of lignin; $1165 \mathrm{~cm}^{-1}-\mathrm{C}-\mathrm{O}-\mathrm{C}$ valence vibrations in cellulose and hemicellulose; $1135-1136 \mathrm{~cm}^{-1}$ C-O-C valence vibrations of lignin (Boeriu et al. 2004; Derkacheva and Sukhov 2008). The spectra of birch and poplar preparations were very similar, in contrast to the spectrum of pine preparation. In particular, this applied to the band $1272 \mathrm{~cm}^{-1}$, which was more intense than the band $1217 \mathrm{~cm}^{-1}$ in the spectrum of pine preparation, as compared to birch and poplar preparations, and also, a redistribution of component deposits in the range from 1150 to $1000 \mathrm{~cm}^{-1}$. 
Table 2 Frequencies of PP

\begin{tabular}{|c|c|}
\hline PP & Frequencies \\
\hline 3375 & str $\mathrm{OH}$ \\
\hline 3283 & str \\
\hline 3186 & str \\
\hline 3061 & str $\mathrm{C}-\mathrm{H}$ aromatic \\
\hline 2983 & str $\mathrm{CH}_{3}$ \\
\hline 2955 & $\operatorname{str} \mathrm{CH}_{3}$ \\
\hline 2916 & str $\mathrm{CH}_{2}$ \\
\hline 2848 & str $\mathrm{CH}_{2}$ \\
\hline \multicolumn{2}{|l|}{2642} \\
\hline \multicolumn{2}{|l|}{2530} \\
\hline & $\operatorname{str} \mathrm{C}=\mathrm{O}$ \\
\hline 1731 & str $-\mathrm{C}=\mathrm{O}$ \\
\hline 1707 & str $-\mathrm{C}=\mathrm{O}$ \\
\hline 1686 & str $-\mathrm{C}=\mathrm{O}$ \\
\hline \multirow[t]{2}{*}{1648} & $\operatorname{str} \mathrm{C}=\mathrm{O}$ \\
\hline & $\operatorname{str} C=C$ \\
\hline 1596 & $\operatorname{str} \mathrm{C}=\mathrm{C}$ \\
\hline 1546 & $\operatorname{str} C=C$ \\
\hline 1504 & $\operatorname{str} \mathrm{C}=\mathrm{C}$ \\
\hline 1450 & asym def $\mathrm{CH}_{3}$ \\
\hline 1408 & $\operatorname{def} \mathrm{CH}$, def $\mathrm{CH}_{2}$ \\
\hline \multicolumn{2}{|l|}{1316} \\
\hline \multicolumn{2}{|l|}{1295} \\
\hline 1268 & $\mathrm{C}-\mathrm{O}$ \\
\hline 1177 & $\mathrm{C}-\mathrm{O}-\mathrm{C}$ \\
\hline \multicolumn{2}{|l|}{1134} \\
\hline 1095 & $\mathrm{C}-\mathrm{O}$ \\
\hline \multicolumn{2}{|l|}{1071} \\
\hline \multicolumn{2}{|l|}{1018} \\
\hline \multicolumn{2}{|l|}{943} \\
\hline 927 & \\
\hline
\end{tabular}

Burning plastics releases the products of decomposition and oxidation of the polymers. The higher the combustion temperature, the higher the variety of types of combustion products is. In the PET sample before combustion, the characteristic bands were the deformation vibration of the $\mathrm{CH}$ in the range of $1370-1340 \mathrm{~cm}^{-1}$, the contribution of which can determine the presence of amorphous and crystalline phases in the plastic. Plastic smokes were characterized by the presence of wide absorption band in the region of $3400 \mathrm{~cm}^{-1}$, which referred to the stretching vibrations of hydrogen-bound $\mathrm{OH}$ molecular groups. The region of $3000-3100 \mathrm{~cm}^{-1}$, referred to $\mathrm{CH}$ ring vibrations and the region of $2920-2880 \mathrm{~cm}^{-1}$, to the stretching vibrations of $\mathrm{CH}_{2}, \mathrm{CH}_{3}$. The region of $1800-1650 \mathrm{~cm}^{-1}$ was the absorption of $\mathrm{C}=\mathrm{O}$ molecular groups. According to literature data in the original plastic, the $\mathrm{C}=\mathrm{O}$ vibration was located at $1720 \mathrm{~cm}^{-1}$, and after combustion, it was at $1685 \mathrm{~cm}^{-1}$, and there was a very intense shoulder in $1731 \mathrm{~cm}^{-1}$ in plastic smoke (Fabia et al. 2020), and these literature data are in accordance with our spectra (Fig. 4, Table 2).

\section{Neuroactive properties of WP}

\section{Spontaneous and induced ROS generation in nerve terminals in the presence of WP}

To elucidate whether WP influenced redox state of nerve terminals and to compare obtained results with action of PP, the kinetics of ROS generation was monitored using fluorescent dye H2-DCFDA (see "Methods and materials" section). Figure 5a compares the effects of WP (poplar wood) versus PP on the level of ROS, which are spontaneously generated by nerve terminals due to their normal metabolic activity. WP (like PP) significantly and dose-dependently decreased spontaneous ROS production; however, it showed much higher antioxidant efficiency than PP.

Antioxidant effect of WP became much more pronounced after the application of a highly reactive hydrogen peroxide to synaptosomes. As shown in Fig. 5b, pre-incubation of synaptosomes with different aliquots of WP significantly (up to $100 \%$ ) inhibited ROS generation induced by $\mathrm{H}_{2} \mathrm{O}_{2}$ $(50 \mu \mathrm{M})$. Similarly with spontaneous ROS production, WP also decreased $\mathrm{H}_{2} \mathrm{O}_{2}$ action approximately 50 times more effectively than PP. It should be emphasized that such a powerful antioxidant effect of WP was observed regardless of whether it was preliminary added to the synaptosomes, or it was pre-incubated with $\mathrm{H}_{2} \mathrm{O}_{2}$ for 5-10 min before addition (data not shown).

It is important to note that WP was able to neutralize effectively ROS not only exogenously added to synaptosomes (like $\mathrm{H}_{2} \mathrm{O}_{2}$ ) but also generated within synaptosomes due to intracellular signaling pathways. Figure $5 \mathrm{c}$ depicts a dose-dependent effect of WP on the intracellular ROS generation in response to the addition of kainate $(0.2 \mathrm{mM})$, an agonist of kainate/AMPA type glutamate receptors. As seen, pre-incubation of synaptosomes with high concentrations of WP completely inhibited kainate-induced ROS production, thereby affecting the receptor-mediated signaling pathways.

\section{Effect of WP on the membrane potential of nerve terminals and $\mathrm{H}_{2} \mathrm{O}_{2}$-induced depolarization}

The antioxidant properties of WP were also manifested when studying its effect on $\mathrm{H}_{2} \mathrm{O}_{2}$-induced depolarization of the synaptosomal membrane (Fig. 6). As shown in Fig. 6a, application of WP to the synaptosomes, preequilibrated with a membrane potential-sensitive fluorescent dye rhodamine $6 \mathrm{G}$ at a concentration of $20 \mu \mathrm{g} /$ $\mathrm{ml}$, did not significantly affect the membrane potential 
a

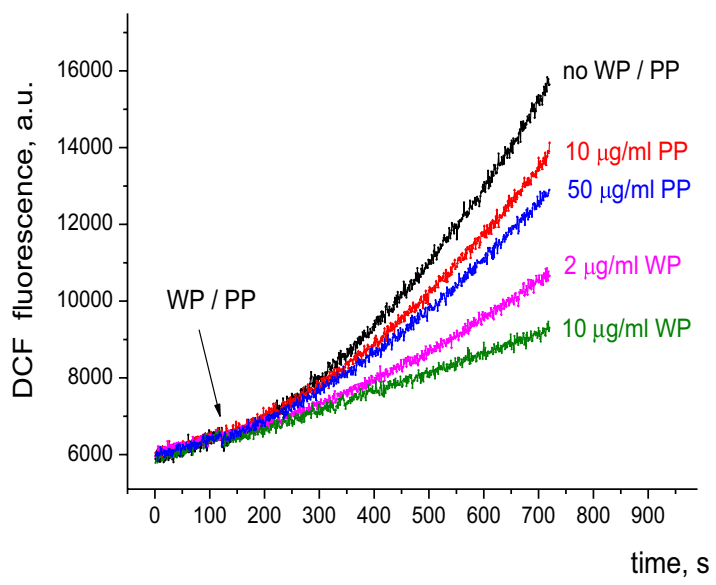

c

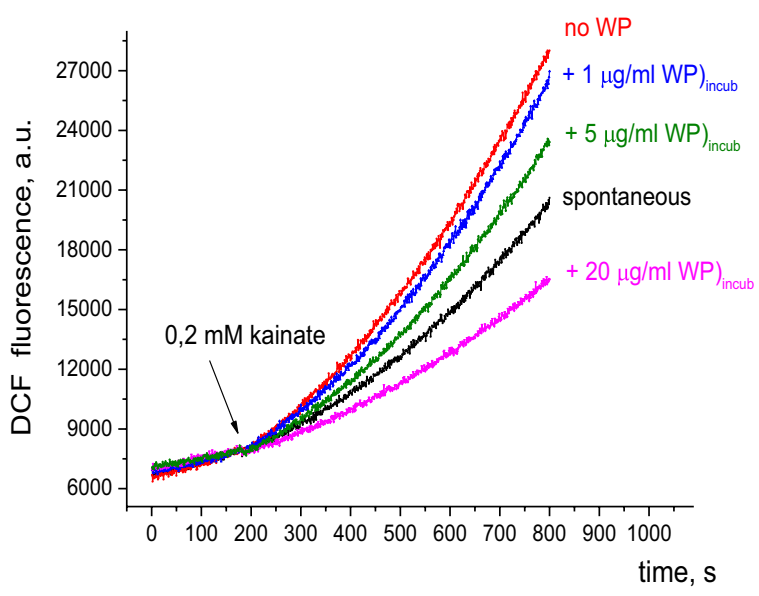

Fig. 5 Comparison of the effects of WP (poplar wood) versus PP on the spontaneous (a) and $50 \mu \mathrm{M} \mathrm{H}_{2} \mathrm{O}_{2}$-induced (b) ROS generation in nerve terminals. Effect of WP (pine wood) on kainate-induced ROS

but considerably reduced the depolarizing effect of $\mathrm{H}_{2} \mathrm{O}_{2}$ $(100 \mu \mathrm{M})$ added $5 \mathrm{~min}$ after WP. However, at higher concentrations, WP itself caused depolarization of the synaptosomal membrane and also inhibited the action of $\mathrm{H}_{2} \mathrm{O}_{2}$ much more significantly. As shown in the inset of Fig. 6a, the effect of WP was concentration-dependent and $\mathrm{H}_{2} \mathrm{O}_{2}$-induced depolarization of the synaptosomal membrane was almost completely blocked by WP at a concentration of $100 \mu \mathrm{g} / \mathrm{ml}$. As shown in Fig. 6b, WP was approximately 40 times more effective than PP regarding inhibitory action on $\mathrm{H}_{2} \mathrm{O}_{2}$-induced depolarization of nerve terminal membrane, when comparing WP versus PP concentrations that caused similar effects. These data b

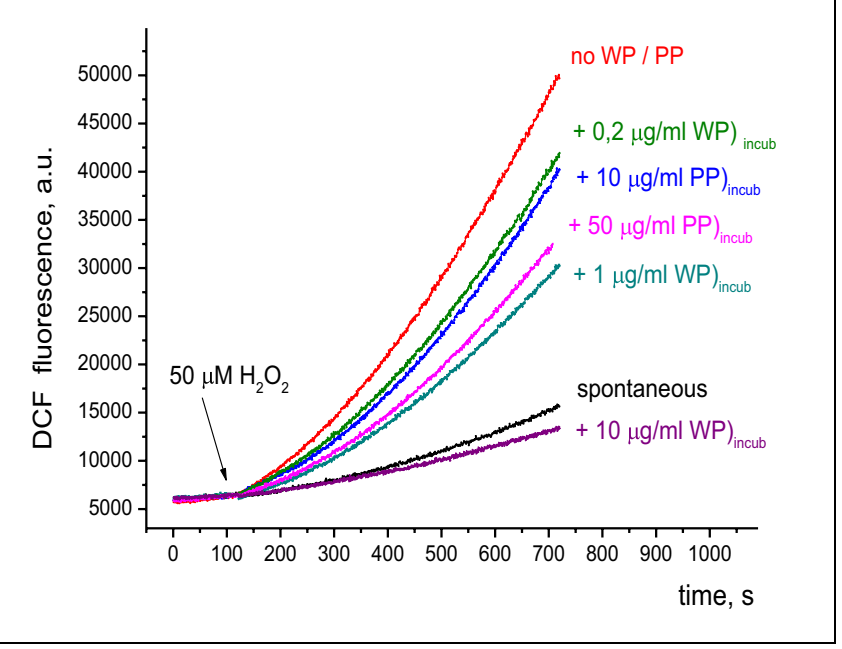

generation (c). Each trace is representative of nine experimental data records performed with different synaptosomal preparations

confirmed that WP has a much higher antioxidant potential than PP.

\section{Transporter-mediated uptake in the presence of WP: the initial rate and accumulation of $\mathrm{L}-\left[{ }^{14} \mathrm{C}\right]$ glutamate and $\left[{ }^{3} \mathrm{H}\right] \mathrm{GABA}$ by nerve terminals}

Figure 7a shows WP-induced dose-dependent decrease in the initial rate of synaptosomal $\mathrm{L}-\left[{ }^{14} \mathrm{C}\right]$ glutamate uptake that was equal to $2.63 \pm 0.18 \mathrm{nmol} / \mathrm{min} / \mathrm{mg}$ of protein in control; $2.03 \pm 0.17 \mathrm{nmol} / \mathrm{min} / \mathrm{mg}$ of protein after application of WP at a concentration of $100 \mu \mathrm{g} / \mathrm{ml}\left[F_{(1,16)}=5.88\right.$; $p<0.05 ; n=9$ ]; and $1.78 \pm 0.23 \mathrm{nmol} / \mathrm{min} / \mathrm{mg}$ of protein 
a

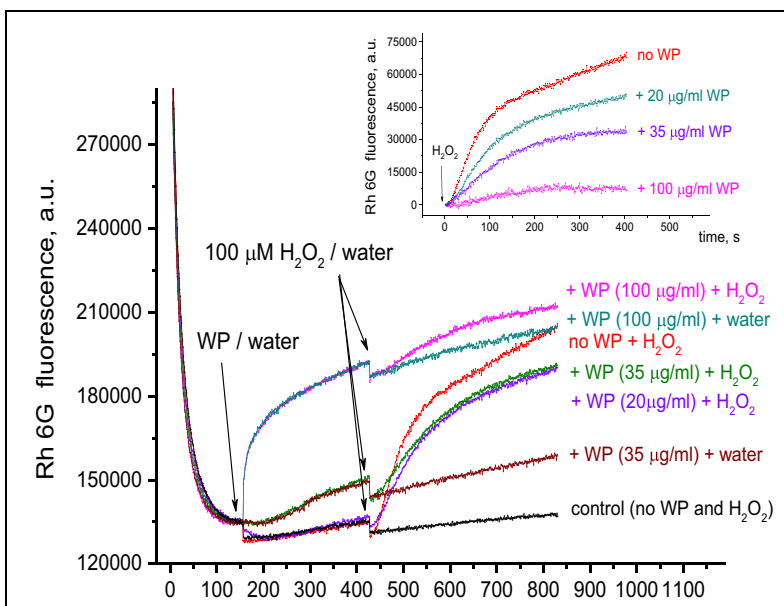

time, s
Fig. 6 a Dose-dependent effect of WP on the membrane potential of nerve terminals and $100 \mu \mathrm{M} \mathrm{H}_{2} \mathrm{O}_{2}$-induced membrane depolarization. Inset depicts $\mathrm{H}_{2} \mathrm{O}_{2}$-induced membrane depolarization at different WP concentrations after subtraction of their corresponding controls (application of water instead of $\mathrm{H}_{2} \mathrm{O}_{2}$ ). b Comparison of the effective

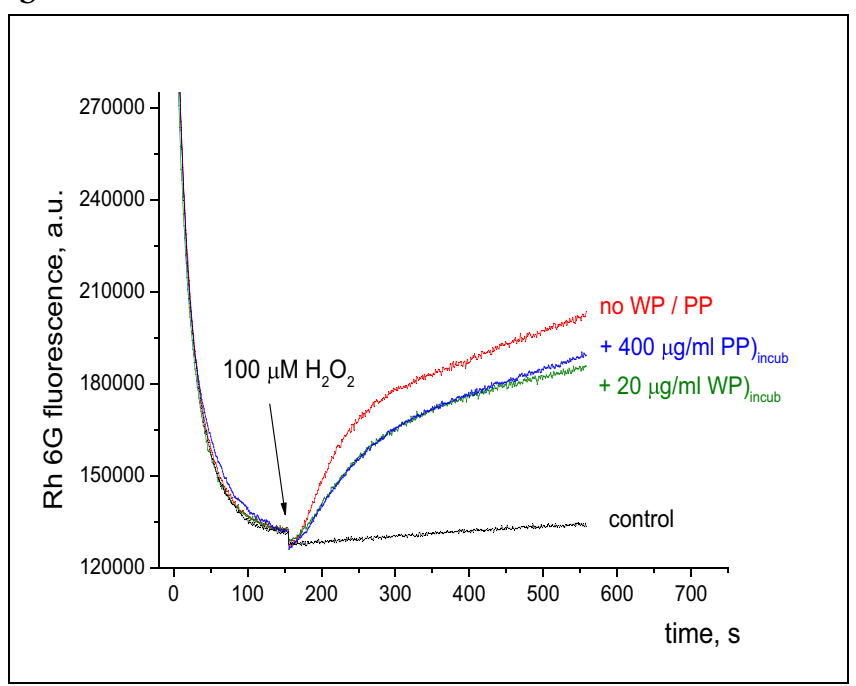

concentrations of WP versus $\mathrm{PP}$, which caused a similar inhibition of $\mathrm{H}_{2} \mathrm{O}_{2}$-induced membrane depolarization of nerve terminals. Each trace is representative of nine experimental data records performed with different synaptosomal preparations

after application of WP at a concentration of $500 \mu \mathrm{g} / \mathrm{ml}$ $\left[F_{(1,16)}=8.72 ; p<0.01\right]$. Synaptosomal L- $\left[{ }^{14} \mathrm{C}\right]$ glutamate accumulation for $10 \mathrm{~min}$ was equal to $10.21 \pm 0.52 \mathrm{nmol} / \mathrm{mg}$ of protein in control; $8.13 \pm 0.39 \mathrm{nmol} / \mathrm{mg}$ of protein after application of WP $(100 \mu \mathrm{g} / \mathrm{ml})\left[F_{(1,16)}=11.64 ; p<0.01\right]$; and $6.57 \pm 0.63 \mathrm{nmol} / \mathrm{mg}$ of protein after application of WP $(500 \mu \mathrm{g} / \mathrm{ml})\left[F_{(1,16)}=22.09 ; p<0.001\right]$. Therefore, the initial rate of synaptosomal uptake of $\mathrm{L}-\left[{ }^{14} \mathrm{C}\right]$ glutamate and its accumulation decreased by $23 \%$ and $20 \%$, respectively, after application of WP at a concentration of $100 \mu \mathrm{g} / \mathrm{ml}$, and these parameters reduced by $32 \%$ and $35 \%$, respectively at a WP concentration of $500 \mu \mathrm{g} / \mathrm{ml}$.

The initial rate of synaptosomal $\left[{ }^{3} \mathrm{H}\right] \mathrm{GABA}$ uptake was equal to $165.47 \pm 10.95 \mathrm{pmol} / \mathrm{min} / \mathrm{mg}$ of protein in control; $125.95 \pm 8.58 \mathrm{pmol} / \mathrm{min} / \mathrm{mg}$ of protein after application of WP $(100 \mu \mathrm{g} / \mathrm{ml})$ [ $\left.F_{(1,16)}=6.7 ; p<0.05 ; n=9\right]$; $103.48 \pm 13.47 \mathrm{pmol} / \mathrm{min} / \mathrm{mg}$ of protein after application of WP $(500 \mu \mathrm{g} / \mathrm{ml})\left[F_{(1,16)}=10.43 ; p<0.01\right]$ (Fig. 7b). Synaptosomal $\left[{ }^{3} \mathrm{H}\right] \mathrm{GABA}$ accumulation for $5 \mathrm{~min}$ was equal to $543.83 \pm 29.67 \mathrm{pmol} / \mathrm{mg}$ of protein in control; $416.94 \pm 32.17$ $\mathrm{pmol} / \mathrm{mg}$ of protein after application of WP $(100 \mu \mathrm{g} / \mathrm{ml})$ $\left[F_{(1,16)}=6.42 ; p<0,05\right]$; and $340.98 \pm 13.75 \mathrm{pmol} / \mathrm{mg}$ of protein after application of WP $(500 \mu \mathrm{g} / \mathrm{ml})\left[F_{(1,16)}=43.29\right.$; $p<0.001]$. Therefore, both the initial rate of synaptosomal uptake of $\left[{ }^{3} \mathrm{H}\right] \mathrm{GABA}$ and its accumulation decreased by $23 \%$ after application of WP at a concentration of $100 \mu \mathrm{g} / \mathrm{ml}$, and both parameters reduced by $37 \%$ at a WP concentration of $500 \mu \mathrm{g} / \mathrm{ml}$. In summary, WP components mitigated
Fig. 7 The initial rate of synaptosomal transporter-mediated uptake and accumulation of L- $\left[{ }^{14} \mathrm{C}\right]$ glutamate $(\mathbf{a})$ and $\left[{ }^{3} \mathrm{H}\right] \mathrm{GABA}(\mathbf{b})$ after application of WP at different concentrations. Data is mean \pm SEM. $* p<0.05 ; * * p<0.01 ; * * * p<0.001$ as compared to control, $n=9$ 
functioning of both excitatory and inhibitory neurotransmitter transporters in nerve terminals.

Comparing with WP, PP also decreased uptake of both $\mathrm{L}-\left[{ }^{14} \mathrm{C}\right]$ glutamate and $\left[{ }^{3} \mathrm{H}\right] \mathrm{GABA}$ by nerve terminals in a similar way and range (Borysov et al. 2020).

\section{A comparative study of the ambient levels of $L-\left[{ }^{14} C\right]$ glutamate and $\left[{ }^{3} \mathrm{H}\right] \mathrm{GABA}$ in nerve terminal preparations in the presence of WP and PP}

\section{$\mathrm{L}-\left[{ }^{14} \mathrm{C}\right]$ glutamate assay}

It was revealed that the ambient levels of L- $\left[{ }^{14} \mathrm{C}\right]$ glutamate in synaptosomal preparations in the presence of WP and PP were not changed considerably and were equal to $16.93 \pm 0.66 \%$ of total accumulated L- $\left[{ }^{14} \mathrm{C}\right]$ glutamate in control; $16.74 \pm 0.68 \%\left[F_{(1,22)}=0.04 ; p=0.85 ; n=12\right]$, and $18.91 \pm 0.66 \%\left[F_{(1,22)}=2.14 ; p=0.16 ; n=12\right]$ after application of 100 and $500 \mu \mathrm{g} / \mathrm{ml} \mathrm{WP}$, respectively. The ambient levels of L- $\left[{ }^{14} \mathrm{C}\right]$ glutamate were equal to $17.29 \pm 0.84 \%$ $\left[F_{(1,22)}=0.11 ; p=0.74 ; n=12\right]$ of total accumulated label after application of $100 \mu \mathrm{g} / \mathrm{ml} \mathrm{PP}$, and $17.86 \pm 1.01 \%$ $\left[F_{(1,22)}=0.59 ; p=0.45 ; n=12\right]$ after application of $500 \mu \mathrm{g} /$ ml PP (Fig. 8a).

\section{$\left[{ }^{3} \mathrm{H}\right] \mathrm{GABA}$ assay}

The ambient levels of $\left[{ }^{3} \mathrm{H}\right] \mathrm{GABA}$ in synaptosomal preparations after application of WP were changed and consisted of $10.78 \pm 0.35 \%$ of total accumulated $\left[{ }^{3} \mathrm{H}\right] \mathrm{GABA}$ in control; $14.36 \pm 1.08 \%\left[F_{(1,22)}=10.88 ; p<0.01 ; n=12\right]$ after application of $100 \mu \mathrm{g} / \mathrm{ml} \mathrm{WP}$; and $29.64 \pm 1.65 \%\left[F_{(1,22)}=138.3\right.$; $p<0.001 ; n=12]$ after application of $500 \mu \mathrm{g} / \mathrm{ml} \mathrm{WP}$ (Fig. 8b).

Whereas, oppositely directed changes as compared to WP were shown in the ambient levels of $\left[{ }^{3} \mathrm{H}\right] \mathrm{GABA}$ in synaptosomal preparations after application of PP, and it was revealed that $\mathrm{PP}$ decreased the ambient $\left[{ }^{3} \mathrm{H}\right] \mathrm{GABA}$ level that consisted of $10.11 \pm 0.47 \%$ of total accumulated $\left[{ }^{3} \mathrm{H}\right] \mathrm{GABA}$
$\left[F_{(1,22)}=1.43 ; p=0.24 ; n=12\right]$ after application of $100 \mu \mathrm{g} /$ $\mathrm{ml} \mathrm{PP}$ and $7.45 \pm 0.34 \%\left[F_{(1,22)}=50.27 ; p<0.001 ; n=12\right]$ after application of $500 \mu \mathrm{g} / \mathrm{ml} \mathrm{PP} \mathrm{(Fig.} \mathrm{8b).}$

\section{Discussion}

In this study, a comparative assessment of the spectroscopic, fluorescent, oxidative, and neuroactive properties of WP and PP was carried out. Data on dynamic light scattering revealed that WP similarly with PP consisted of major fraction of nano-sized particles (Fig. 1). In this context, both WP and PP possessed unique characteristics inherent to nano-sized particles that in turn can influence their environmental distribution and health effects. Literature data have confirmed that ultrafine air pollution $\mathrm{PM}_{0.1}$ (size of which is less than $0.1 \mu \mathrm{m}$ ) is extra hazardous to human health in comparison with fine $\mathrm{PM}_{2.5}$ and coarse $\mathrm{PM}_{10}$ (Fine et al. 2004; Borisova 2018). The smaller the size of airborne PM, the stronger toxicity through mechanisms of oxidative stress and inflammation can be registered (Valavandis et al. 2008). Both WP and PP demonstrated the main optical absorption in the UV region within the range of 200-350 $\mathrm{nm}$, but in contrast to PP, WP had a pronounced peak at around $275 \mathrm{~nm}$ (Fig. 2). Such high-energy absorbance band may be attributed to guaiacol- and syringol-type compounds, which are the major components of wood smoke and are formed as a result of lignin degradation. Lignin is a branched biopolymer that together with hemicelluloses and pectin acts as an adhesive matrix for cellulose microfibrils. In softwood, lignin consists mainly of guaiacil units, i.e., the structure of lignin is derived from coniferyl alcohol, while hardwood shells consist mainly of syringil derived from mustard alcohol. The main components of wood were cellulose (45-60\%), hemicellulose (15-35\%) and lignin (in conifers up to $35 \%$ by weight in deciduous 20-25\% respectively)(Hon and Shiraishi 2001; Nedukha 2015; Janusz et al. 2017). Absorption data from Fig. 2 were confirmed by Raman and FT6R spectroscopy (Figs. 3 and 4, Tables 1 and 2).
Fig. 8 The ambient levels of $\mathrm{L}-\left[{ }^{14} \mathrm{C}\right]$ glutamate $(\mathbf{a})$ and $\left[{ }^{3} \mathrm{H}\right]$ GABA (b) in synaptosomal suspensions in the control group and after application of WP and PP (100-500 $\mu \mathrm{g} / \mathrm{ml})$. The data are the mean \pm SEM. n.s., no significant differences; $* * p<0.01 ; * * * p<0.001$ as compared to control; $n=12$

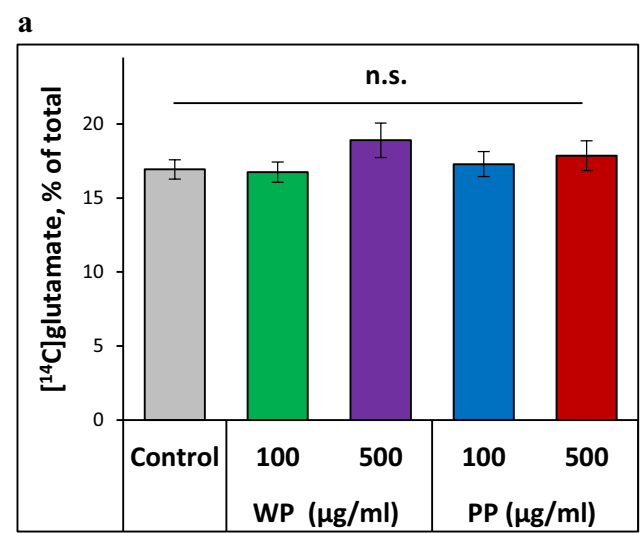

b

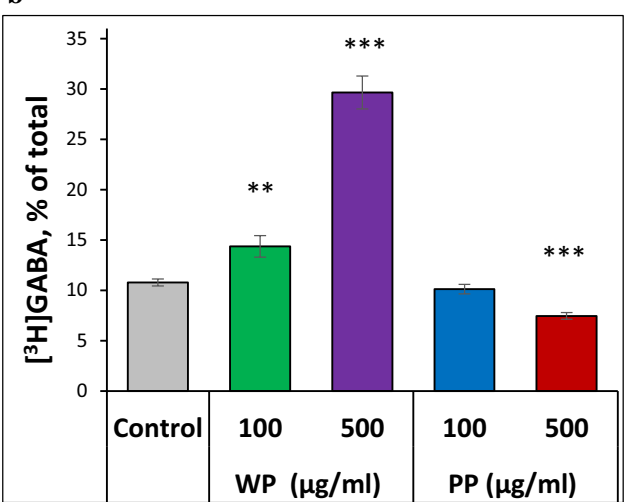


Oxidative properties of WP and PP in nerve terminals were unidirectional but had different efficiency levels (Fig. 5a, b). Comparative analysis of the antioxidant activities of WP versus PP revealed that WP showed much higher antioxidant efficiency than PP in relation to both the spontaneous and induced ROS generation. This may be at least partially explained by the presence in WP not only carbon dots, which were reported to possess antioxidant properties, but also a large amount of methoxyphenols, the structural features of which were similar to those of phenolic antioxidants, such as ubiquinols and tocopherols (Kjällstrand and Petersson 2001). Our findings are consistent with literature data, where plastic organics and carbon nanodots demonstrated antioxidant properties by scavenging oxidant free radicals and ROS, and the carboxyl and amino groups were involved through hydrogen atom transfer reaction ( $\mathrm{Li}$ et al. 2018; Zhang et al. 2018; Ji et al. 2019). As our data demonstrate, WP potently inhibited an increase in ROS generation induced by the activation of kainate-type glutamate receptors, which are known to modulate synaptic transmission and synaptogenesis (Fig. 5c). In particular, we have previously shown that presynaptic glutamate receptor-mediated ROS production was tightly coupled with the modulation of GABA release from cortical and hippocampal nerve terminals (Tarasenko et al. 2012). In this context, and given the numerous evidence about the important role of ROS in the regulation of neurotransmission and synaptic plasticity (Massaad and Klann 2011; Beckhauser et al. 2016; González et al. 2020), the inhibition of kainate-induced ROS production by WP may lead to the disruption of receptor-mediated signaling pathways and so indirectly affects neuronal synaptic activity.

One of the main findings of this study is the fact that PP were able to decrease the ambient level of $\left[{ }^{3} \mathrm{H}\right] \mathrm{GABA}$ (Fig. 8a), whereas the ambient level of L- $\left[{ }^{14} \mathrm{C}\right]$ glutamate remained unchanged (Fig. 8b), and WP did not change both parameters (Fig. 8a, b). It should be emphasized that the extracellular level of neurotransmitters between the episodes of exocytotic release is a balance between transporter-mediated uptake/release and the tonic leakage of neurotransmitters and is a very important characteristic that determines strengths of synaptic contacts and regulates synaptic neurotransmission (Borisova and Borysov 2016; Borisova 2016). Neurochemical mechanisms of the PP-induced attenuation of the ambient $\left[{ }^{3} \mathrm{H}\right] \mathrm{GABA}$ level in nerve terminals (Fig. 8b) despite decreased $\left[{ }^{3} \mathrm{H}\right]$ GABA uptake (Fig. $7 b$ ) can be suggested but needs further detailed examination. Our previous study has revealed a tight correlation between ROS production and GABA secretion in nerve terminals (Tarasenko et al. 2012). A possible explanation was that PP components, but not WP ones, can decrease tonic $\left[{ }^{3} \mathrm{H}\right] \mathrm{GABA}$ leakage from nerve terminals, thereby compensating a decrease in $\left.{ }^{3} \mathrm{H}\right] \mathrm{GABA}$ uptake. Therefore, WP and PP demonstrated neurotoxic features and can provoke malfunction at the presynapse via weakening transporter-mediated glutamate/ GABA uptake by nerve terminals that misbalanced excitatory and inhibitory neurotransmission. Moreover, PP can provoke a decrease in synaptic inhibition via lowering ambient level of GABA in the synaptic cleft. These facts can relate to recently shown association of air pollution by PM with nervous system disorders and neurodegenerative disease, including dementia, cognitive function redaction, attention deficit and hyperactivity in children, autism, stroke, nausea, and headaches (Verma et al. 2016; Landrigan et al. 2018). The central nervous system is not secured against evolutionary new challenge of intensive exposure to anthropogenic carbon-containing air pollution PM (Borisova 2018). Particles can be deposited in the nasal region of humans and move along olfactory nerve axons straight to the brain circumstancing the blood brain barrier (Oberdörster et al. 2005). Also, our data is in accordance with our previous 18 , where we have shown recently in modelling experiments that carbon nanoparticles synthesized by heating of carbohydrates (betaalanine and thiourea) possessed neurotoxic effects (Borisova et al. 2015, 2017). In perspectives, our further efforts will be focused on the analysis of individual effects of separate components of wood sawdust smoke PM on synaptic transmission. We suggest that different types of wood in sawdust can have different effects on excitatory and inhibitory signaling and so differently influence synaptic neurotransmission.

\section{Conclusion}

WP were synthesized from a widespread biomass-based fuel for residential heating, wood sawdust. Synthesized WP contained the major nano-sized PM fraction. Light absorption and fluorescent properties of WP were characterized in details. Neurotoxicity studies using nerve terminals demonstrated that WP attenuated the membrane potential and demonstrated more pronounced reduction of spontaneous and $\mathrm{H}_{2} \mathrm{O}_{2}$-evoked ROS production as compared to PP, thereby influencing synaptosomal oxidative processes. WP and PP provoked presynaptic malfunction reducing the uptake of glutamate and GABA that in turn can misbalance excitatory and inhibitory signaling. Moreover, PP can provoke a decrease in synaptic inhibition via lowering ambient level of GABA in the synaptic cleft. Therefore, WP and PP demonstrated similarity in the PM size, optical properties, effects on the membrane potential, L- $\left[{ }^{14} \mathrm{C}\right]$ glutamate $/\left[{ }^{3} \mathrm{H}\right] \mathrm{GABA}$ uptake and the ambient $\mathrm{L}-\left[{ }^{14} \mathrm{C}\right]$ glutamate level, whereas principal difference was found in synaptosomal ambient level of $\left[{ }^{3} \mathrm{H}\right] \mathrm{GABA}$ between WP and PP that can be a reason for development of neuropathology in response to human exposure to air pollution PM (Table 3). 
Table 3 Comparison of WP and PP properties

\begin{tabular}{|c|c|c|}
\hline Property & WP & PP \\
\hline Size of PM & $30 \mathrm{~nm}$ & $34 \mathrm{~nm}$ \\
\hline $\begin{array}{l}\text { Optical properties } \\
\text { (absorbance) }\end{array}$ & One peak in the region $200-270 \mathrm{~nm}$ & One peak in the region $250-300 \mathrm{~nm}$ \\
\hline Fluorescent properties & $\begin{array}{l}\text { Strong photo luminescence in the vis- } \\
\text { ible and near-infrared range }\end{array}$ & $\begin{array}{l}\text { Strong photoluminescence in the } \\
\text { mid infrared range }\end{array}$ \\
\hline The synaptosomal membrane potential & Decreased & Decreased \\
\hline $\begin{array}{l}\text { Spontaneous and } \mathrm{H}_{2} \mathrm{O}_{2} \text {-evoked ROS generation in nerve termi- } \\
\text { nals }\end{array}$ & Decreased to the lesser extent than PP & Decreased \\
\hline $\mathrm{L}-\left[{ }^{14} \mathrm{C}\right]$ glutamate $/\left[{ }^{3} \mathrm{H}\right] \mathrm{GABA}$ uptake by nerve terminals & Decreased & Decreased \\
\hline The ambient level of $\mathrm{L}-\left[{ }^{14} \mathrm{C}\right]$ glutamate in nerve terminals & Not changed & Not changed \\
\hline The ambient level of $\left[{ }^{3} \mathrm{H}\right] \mathrm{GABA}$ in nerve terminals & Not changed & Decreased \\
\hline
\end{tabular}

Acknowledgements We thank Dr. A. Chunihin from the Palladin Institute of Biochemistry for helping in dynamic light scattering experiments and M. Dudarenko for the excellent technical assistance in GABA-related experiments; Prof. G. Milinevsky from Taras Shevchenko University of Kyiv for providing mini laser $\mathrm{PM}_{2.5}$ monitor/ SDL607counter.

Author contribution Synthesis and collection of WP and PP, measurements of their size, monitoring $\mathrm{PM}_{2.5}$ emission were carried out by $\mathrm{AB}$ and KP; dynamic light scattering, AB; optical properties of WP-KP and synaptosome isolation, AP; spectrofluorimetry using synaptosomes, AT; L- $\left[{ }^{14} \mathrm{C}\right]$ glutamate experiments, AP and NK; $\left[{ }^{3} \mathrm{H}\right] \mathrm{GABA}$ experiments, NP; FTIR spectra, OS; Raman spectra, GD and OG; data analysis, TB, NP, NK, AT, OS, GD, and OG. Experimental design and draft paper writing was done by TB. The final version of the MS was revised and approved by all co-authors.

Funding This work was supported by the grant of National Research Foundation of Ukraine \# 2020.02/0147; PI: Prof. T. Borisova.

Data Availability The authors declare that all data supporting the findings of this study are available within the article and its supplementary information files.

\section{Declarations}

Ethics approval All experiments using rats were conducted according to the Guidelines of the European Community (2010/63/EU), and the local laws and policies, and were preliminary approved by the Animal Care and Use Committee of the Institute (the Protocol \#5 from 01/09/2020). The studies are in accordance with the ARRIVE guidelines for reporting experiments involving animals (McGrath et al. 2010).

Consent to participate Not applicable.

Consent for publication Not applicable.

Competing interests The authors declare competing interests.

\section{References}

Beckhauser TF, Francis-Oliveira J, De Pasquale R (2016) Reactive oxygen species: physiological and physiopathological effects on synaptic plasticity. J Exp Neurosci 2016:23-48. https://doi.org/ 10.4137/JEN.S39887

Boeriu CG, Bravo D, Gosselink RJA, Van Dam JEG (2004) Characterisation of structure-dependent functional properties of lignin with infrared spectroscopy. Ind Crops Prod 20:205-218. https:// doi.org/10.1016/j.indcrop.2004.04.022

Borisova T (2016) Permanent dynamic transporter-mediated turnover of glutamate across the plasma membrane of presynaptic nerve terminals: arguments in favor and against. Rev Neurosci 27:71-81. https://doi.org/10.1515/revneuro-2015-0023

Borisova T (2019) Express assessment of neurotoxicity of particles of planetary and interstellar dust. npj Microgravity 5:2. https://doi. org/10.1038/s41526-019-0062-7

Borisova T (2018) Nervous system injury in response to contact with environmental, engineered and planetary micro- and nano-sized particles. Front Physiol 9:728. https://doi.org/10.3389/fphys.2018. 00728

Borisova T (2014) The neurotoxic effects of heavy metals: alterations in acidification of synaptic vesicles and glutamate transport in brain nerve terminals. Horizons Neurosci Res 14:89-112

Borisova T, Borysov A (2016) Putative duality of presynaptic events. Rev Neurosci 27:377-383

Borisova T, Borysov A, Pastukhov A, Krisanova N (2016) Dynamic gradient of glutamate across the membrane: glutamate/aspartateinduced changes in the ambient level of L-[(14)C]glutamate and D-[(3)H]aspartate in rat brain nerve terminals. Cell Mol Neurobiol 36:1229-1240. https://doi.org/10.1007/s10571-015-0321-4

Borisova T, Dekaliuk M, Pozdnyakova N et al (2017) Harmful impact on presynaptic glutamate and GABA transport by carbon dots synthesized from sulfur-containing carbohydrate precursor. Environ Sci Pollut Res 24:17688-17700. https://doi.org/10.1007/ s11356-017-9414-6

Borisova T, Komisarenko S (2020) Air pollution particulate matter as a potential carrier of SARS-CoV-2 to the nervous system and/ or neurological symptom enhancer: arguments in favor. Environ Sci Pollut Res 28:40371-40377. https://doi.org/10.1007/ s11356-020-11183-3

Borisova T, Krisanova N, Himmelreich N (2004) Exposure of animals to artificial gravity conditions leads to the alteration of the glutamate release from rat cerebral hemispheres nerve terminals. Adv Sp Res 33:1362-1367. https://doi.org/10.1016/j.asr.2003.09.039

Borisova T, Nazarova A, Dekaliuk M et al (2015) Neuromodulatory properties of fluorescent carbon dots: effect on exocytotic release, uptake and ambient level of glutamate and GABA in brain nerve terminals. Int J Biochem Cell Biol 59:203-215. https://doi.org/10. 1016/j.biocel.2014.11.016 
Borisova TA, Himmelreich NH (2005) Centrifuge-induced hypergravity: $[3 \mathrm{H}] \mathrm{GABA}$ and 1-[14C]glutamate uptake, exocytosis and efflux mediated by high-affinity, sodium-dependent transporters. Adv Sp Res 36:1340-1345. https://doi.org/10.1016/j.asr.2005.10. 007

Borysov A, Krisanova N, Chunihin O et al (2014) A comparative study of neurotoxic potential of synthesized polysaccharide-coated and native ferritin-based magnetic nanoparticles. Croat Med J 55:195205. https://doi.org/10.3325/cmj.2014.55.195

Borysov A, Pozdnyakova N, Pastukhov A, Borisova T (2018) Comparative analysis of neurotoxic potential of synthesized, native, and physiological nanoparticles. In: Santamaria, F. Peralta X (ed) Use of nanoparticles in neuroscience. Neuromethods 135, Chapter 13, Springer. Humana Press, New York, V 135, pp 203-227. https:// doi.org/10.1007/978-1-4939-7584-6_13

Borysov A, Tarasenko A, Krisanova N et al (2020) Plastic smoke aerosol: nano-sized particle distribution, absorption/fluorescent properties, dysregulation of oxidative processes and synaptic transmission in rat brain nerve terminals. Environ Pollut 263:114502. https://doi.org/10.1016/j.envpol.2020.114502

Cotman CW (1974) Isolation of synaptosomal and synaptic plasma membrane fractions. Methods Enzymol 31:445-452

Derkacheva O, Sukhov D (2008) Investigation of lignins by FTIR spectroscopy. Macromol Symp 265:61-68. https://doi.org/10. 1002/masy.200850507

Deuschl G, Beghi E, Fazekas F et al (2020) The burden of neurological diseases in Europe: an analysis for the Global Burden of Disease Study 2017. Lancet Public Heal 5:e551-e567. https:// doi.org/10.1016/S2468-2667(20)30190-0

Dias Júnior AF, de Oliveira RN, Deglise X et al (2019) Infrared spectroscopy analysis on charcoal generated by the pyrolysis of Corymbia citriodora wood. Rev Mater 24:e12387. https://doi. org/10.1590/s1517-707620190003.0700

Fabia J, Gawłowski A, Rom M et al (2020) PET fibers modified with cloisite nanoclay. Polymers (basel) 12:774. https://doi.org/10. 3390/POLYM12040774

Fan X, Wei S, Zhu M et al (2016) Comprehensive characterization of humic-like substances in smoke $\mathrm{PM}_{2.5}$ emitted from the combustion of biomass materials and fossil fuels. Atmos Chem Phys 16:13321-13340. https://doi.org/10.5194/acp-16-13321-2016

Fine PM, Shen S, Sioutas C (2004) Inferring the sources of fine and ultrafine particulate matter at downwind receptor sites in the los angeles basin using multiple continuous measurements special issue of aerosol science and technology on findings from the fine particulate matter S. Aerosol Sci Technol 38:182-195. https://doi.org/10.1080/02786820390229499

Fuzzi S, Baltensperger U, Carslaw K et al (2015) Particulate matter, air quality and climate: lessons learned and future needs. Atmos Chem Phys 15:8217-8299. https://doi.org/10.5194/ acp-15-8217-2015

Gilardoni S, Massoli P, Paglione M et al (2016) Direct observation of aqueous secondary organic aerosol from biomass-burning emissions. Proc Natl Acad Sci U S A 113:10013-10018. https:// doi.org/10.1073/pnas.1602212113

González ANB, Pazos MIL, Calvo DJ (2020) Reactive oxygen species in the regulation of the GABA mediated inhibitory neurotransmission. Neuroscience 439:137-145. https://doi.org/10. 1016/j.neuroscience.2019.05.064

Hon DNS, Shiraishi N (2001) Wood and cellulosic chemistry, revised, and expanded, 2nd Editio. CRC PreSS Taylor \& Francis Group, New York, NY

Janusz G, Pawlik A, Sulej J et al (2017) Lignin degradation: microorganisms, enzymes involved, genomes analysis and evolution. FEMS Microbiol Rev 41:941-962. https://doi.org/10.1093/ femsre/fux049
Jarrahi A, Ahluwalia M, Khodadadi H et al (2020) Neurological consequences of COVID-19: what have we learned and where do we go from here? J Neuroinflammation 17:1-12. https://doi. org/10.1186/s12974-020-01957-4

Ji Z, Sheardy A, Zeng Z et al (2019) Tuning the functional groups on carbon nanodots and antioxidant studies. Molecules 24:152. https://doi.org/10.3390/molecules24010152

Jiang X, Zhang Q, Zhao H et al (2015) Revealing the hidden health costs embodied in Chinese exports. Environ Sci Technol 49:4381-4388. https://doi.org/10.1021/es506121s

Jonsson R, Rinaldi F (2017) The impact on global wood-product markets of increasing consumption of wood pellets within the European Union. Energy 133:864-878. https://doi.org/10. 1016/j.energy.2017.05.178

Karthika C, Swathy Krishna R, Rahman MH, Akter R, Kaushik D (2021) COVID-19, the firestone in 21st century: a review on coronavirus disease and its clinical perspectives. Environ Sci Pollut Res 28:64951-64966. https://doi.org/10.1007/ s11356-021-16654-9

Kjällstrand J, Petersson G (2001) Phenolic antioxidants in wood smoke. Sci Total Environ 277:69-75. https://doi.org/10.1016/ S0048-9697(00)00863-9

Kubovský I, Kačíková D, Kačík F (2020) Structural changes of oak wood main components caused by thermal modification. Polymers (basel) 12:485. https://doi.org/10.3390/polym12020485

Landrigan PJ, Fuller R, Acosta NJR et al (2018) The Lancet Commission on pollution and health. Lancet 391:462-512. https://doi.org/ 10.1016/S0140-6736(17)32345-0

Larson E, Howlett B, Jagendorf A (1986) Artificial reductant enhancement of the Lowry method for protein determination. Anal Biochem 155:243-248

Li D, Na X, Wang H et al (2018) Fluorescent carbon dots derived from maillard reaction products: their properties, biodistribution, cytotoxicity, and antioxidant activity. J Agric Food Chem 66:1569-1575. https://doi.org/10.1021/acs.jafc.7b05643

Liu J, Li R, Yang B (2020) Carbon dots: a new type of carbon-based nanomaterial with wide applications. ACS Cent Sci 6:2179-2195. https://doi.org/10.1021/acscentsci.0c01306

McGrath JC, Drummond GB, McLachlan EM et al (2010) Guidelines for reporting experiments involving animals: the ARRIVE guidelines. Br J Pharmacol 160:1573-1576. https://doi.org/10.1111/j. 1476-5381.2010.00873.x

Massaad CA, Klann E (2011) Reactive oxygen species in the regulation of synaptic plasticity and memory. Antioxid Redox Signal 14(10):2013-2054. https://doi.org/10.1089/ars.2010.3208

Nedukha O (2015) Cell wall of plants and environment (Клітинна оболонка рослин і фактори середовища). Alterpress, Kiev, Ukraine

Oberdörster G, Oberdörster E, Oberdörster J (2005) Nanotoxicology: an emerging discipline evolving from studies of ultrafine particles. Environ Health Perspect 113:823-839. https://doi.org/10.1289/ ehp.7339

Pozdnyakova N (2017) Consequences of perinatal hypoxia in developing brain: changes in GABA transporter functioning in cortical, hippocampal and thalamic rat nerve terminals. Int J Dev Neurosci 63:1-7. https://doi.org/10.1016/j.ijdevneu.2017.09.002

Pozdnyakova N, Dudarenko M, Borisova T (2015) New effects of GABAB receptor allosteric modulator rac-BHFF on ambient GABA, uptake/release, Em and synaptic vesicle acidification in nerve terminals. Neuroscience 304:60-70

Pozdnyakova N, Pastukhov A, Dudarenko M et al (2016) Neuroactivity of detonation nanodiamonds: dose-dependent changes in transporter-mediated uptake and ambient level of excitatory/inhibitory neurotransmitters in brain nerve terminals. J Nanobiotechnology 14:25. https://doi.org/10.1186/s12951-016-0176-y 
Rahman MH, Akter R, Behl T, Chowdhury MAR, Mohammed M, Bulbul IJ, Elshenawy SI, Kamal MA (2020) COVID-19 outbreak and emerging management through pharmaceutical therapeutic strategy. Curr Pharm Des 26(41):5224-5240. https://doi.org/10. 2174/1381612826666200713174140

Saosee P, Sajjakulnukit B, Gheewala SH (2020) Life cycle assessment of wood pellet production in Thailand. Sustain 12:6996. https:// doi.org/10.3390/su12176996

Soldatkin O, Nazarova A, Krisanova N et al (2015) Monitoring of the velocity of high-affinity glutamate uptake by isolated brain nerve terminals using amperometric glutamate biosensor. Talanta 135:67-74. https://doi.org/10.1016/j.talanta.2014.12.031

Sun L, Niquidet K (2017) Elasticity of import demand for wood pellets by the European Union. For Policy Econ 81:83-87. https://doi.org/ 10.1016/j.forpol.2017.02.001

Tarasenko A, Krupko O, Himmelreich N (2012) Reactive oxygen species induced by presynaptic glutamate receptor activation is involved in $\left[{ }^{3} \mathrm{H}\right] \mathrm{GABA}$ release from rat brain cortical nerve terminals. Neurochem Int 61:1044-1051. https://doi.org/10.1016/j. neuint.2012.07.021

Tarasenko AS, Sivko RV, Krisanova NV, Himmelreich NH, Borisova TA (2010) Cholesterol depletion from the plasma membrane impairs proton and glutamate storage in synaptic vesicles of nerve terminals. J Mol Neurosci 41(3):358-367. https://doi.org/10.1007/ s12031-010-9351-z

The Lancet Neurology (2021) Long COVID: understanding the neurological effects. Lancet Neurol 20:247. https://doi.org/10.1016/ S1474-4422(21)00059-4

Thraen D, Schaubachand Kay (2017) Global wood pellet industry and trade study 2017. IEA Bioenergy, Brussels, Belgium

Timar MC, Varodi A, Hacibektasoglu M, Campean M (2016) Color and FTIR analysis of chemical changes in beech wood (Fagus sylvatica $L$ ) after light steaming and heat treatment in two different environments. BioResources 11:8325-8343. https://doi.org/10. 15376/biores.11.4.8325-8343

Valavandis A, Fiotakis K, Vlachogianni T (2008) Airborne particulate matter and human health: toxicological assessment and importance of size and composition of particles for oxidative damage and carcinogenic mechanisms. J Environ Sci Heal Part C 26:339 362. https://doi.org/10.1080/10590500802494538

Verma R, Vinoda KS, Papireddy M, Gowda ANS (2016) Toxic pollutants from plastic waste- a review. Procedia Environ Sci 35:701708. https://doi.org/10.1016/J.PROENV.2016.07.069

Woo J, Song Y, Ahn J, Kim H (2020) Green one-pot preparation of carbon dots (CD)-embedded cellulose transparent film for Fe3+ indicator using ionic liquid. Cellulose 27:4609-4621. https://doi. org/10.1007/s10570-020-03099-5

World Pellet Map - European Pellet Council. https://epc.bioenergye urope.org/about-pellets/pellets-statistics/world-pellet-map/. Accessed 18 May 2021

Zhang Q, Jiang X, Tong D et al (2017) Transboundary health impacts of transported global air pollution and international trade. Nature 543:705-709. https://doi.org/10.1038/nature21712

Zhang W, Chavez J, Zeng Z et al (2018) Antioxidant capacity of nitrogen and sulfur codoped carbon nanodots. ACS Appl Nano Mater 1:2699-2708. https://doi.org/10.1021/acsanm.8b00404

Zhong M, Jang M (2014) Dynamic light absorption of biomassburning organic carbon photochemically aged under natural sunlight. Atmos Chem Phys 14:1517-1525. https://doi.org/10.5194/ acp-14-1517-2014

Publisher's Note Springer Nature remains neutral with regard to jurisdictional claims in published maps and institutional affiliations. 